\title{
WestVirginiaUniversity
}

THE RESEARCH REPOSITORY @ WVU

Graduate Theses, Dissertations, and Problem Reports

2005

\section{Three essays on the impacts of land -use regulations and land development}

\author{
Gi-Don An \\ West Virginia University
}

Follow this and additional works at: https://researchrepository.wvu.edu/etd

\section{Recommended Citation}

An, Gi-Don, "Three essays on the impacts of land -use regulations and land development" (2005). Graduate Theses, Dissertations, and Problem Reports. 4133.

https://researchrepository.wvu.edu/etd/4133

This Dissertation is protected by copyright and/or related rights. It has been brought to you by the The Research Repository @ WVU with permission from the rights-holder(s). You are free to use this Dissertation in any way that is permitted by the copyright and related rights legislation that applies to your use. For other uses you must obtain permission from the rights-holder(s) directly, unless additional rights are indicated by a Creative Commons license in the record and/ or on the work itself. This Dissertation has been accepted for inclusion in WVU Graduate Theses, Dissertations, and Problem Reports collection by an authorized administrator of The Research Repository @ WVU.

For more information, please contact researchrepository@mail.wvu.edu. 


\title{
Three Essays on the Impacts of Land-Use Regulations and Land Development
}

\section{Gi-Don An}

\author{
Dissertation Submitted to the \\ College of Business and Economics at \\ West Virginia University \\ in partial fulfillment of the requirements for the degree of \\ Doctor of Philosophy \\ In \\ Economics
}
Santiago M. Pinto, Ph.D., Chair
Stratford M. Douglas, Ph.D.
Randall W. Jackson, Ph.D.
Brian J. Cushing, Ph.D.
Russell S. Sobel, Ph.D.

Department of Economics

Morgantown, West Virginia 2005

Keywords: land-use regulations, housing prices, redevelopment,
neighborhood spillovers, spatial dependence

Copyright (C) 2005 Gi-Don An 


\section{Abstract \\ Three Essays on the Impacts of Land-Use Regulations and Land Development}

\section{Gi-Don An}

This dissertation is a collection of essays examining the effects of land-use regulations and redevelopment. The first chapter describes an overview of the Korean housing market.

Chapter 2 employs the stock-flow model in order to incorporate land-use regulation into the analysis. Future land supply can not only constrain housing construction but also affect the people's expectation. Land-use regulations can be incorporated into demand for housing as well as housing construction.

Chapter 3 investigates the impact of land-use regulations on housing market in the case of South Korea. The South Korean rapid income and population growth have produced a sharp increase in housing demand. On the supply side, however, the government has played a crucial role in controlling the housing supply with various regulations in housing and land markets. Much of literature has argued that a shortage of land supply increases housing prices. This paper analyzes the mechanism by which landuse regulations affect housing prices and housing construction. The empirical examination provides that land-use regulations have no binding effects on housing production but raise housing prices by stimulating higher investment demand for housing. The expectation about a shortage of land supply leads to higher future housing prices which in turn spur the current demand. The resulting higher housing prices encourage more housing production by constructing high-rising housing buildings.

Chapter 4 examines the anticipated impact on housing prices of a New Town Development in Seoul announced in 2002. Since the extensive land redevelopment project leads to significant change in residential neighborhoods, it generates spillover effects on the values of housing units located in close proximity. We employ a spatial hedonic housing price model to estimate and measure the spillover impacts of redevelopment with different mixed land uses on surrounding housing prices. The empirical results show that neighborhood spillovers of redevelopment depend on the type of mixed land uses. Housing prices within one kilometer of residential redevelopment mixed with open space were 17 percent higher than elsewhere while houses within one kilometer of residential redevelopment mainly mixed with commercial uses have a higher value of 35 percent compared to those farther away. The empirical results of a pre-post approach suggest that the change in housing prices takes place the year the announcement was made, which implies that housing markets anticipate the future effects of the completed project.

The last chapter summarizes the major findings of the previous chapters and discusses areas of future research. 


\section{ACKNOWLEDGEMENTS}

First of all, I would like to thank my advisor, Dr. Santiago Pinto for his invaluable support, guidance, and critical thinking throughout this dissertation. This dissertation would not have been possible without his patience and understanding. Special thanks to Dr. Douglas for his thoughtful advice to overcome a lot of ordeals and the guidance about a lot of econometric work. I thank Dr. Sobel and Dr. Cushing for their encouragement and thoughtful comments. I extend my gratitude to Dr. Jackson for his friendly discussion.

I would also like to thank Dr. Hyungna Oh for her encouragement and discussion for my dissertation. 
To my wife, Eunhee Han, who has always given me her full support. 


\section{Table of Contents}

Chapter 1:

Introduction, Brief Overview of the Korean Housing Market and

Dissertation Outline

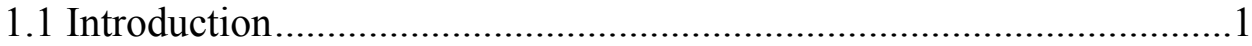

1.2 Brief Overview of the Korean Housing Market .................................2

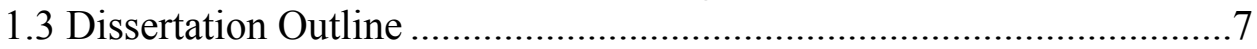

Chapter 2:

Overview of The Stock-Flow Model

2.1 The Market for Housing Services .......................................................12

2.2 The Market for Housing Capital ......................................................12

2.3 Construction............................................................................... 19

2.4 Steady-State Solution and Elasticity .............................................22

Chapter 3:

Land-Use Regulation and the Housing Market in the Case of Korea

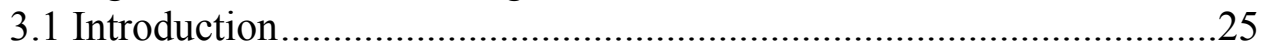

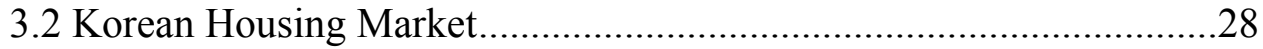

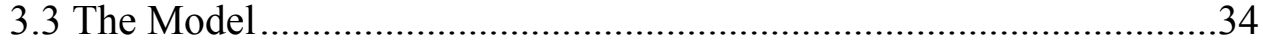

3.4 Data and Variable Definitions ........................................................44

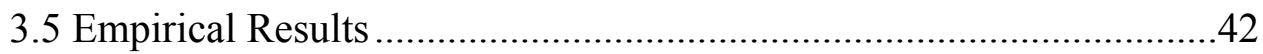

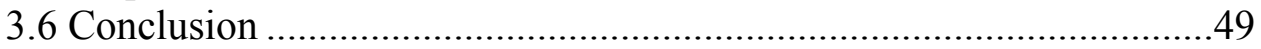

Chapter 4:

The Impact of New Urbanist Redevelopment on Housing Prices

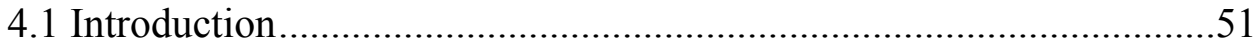

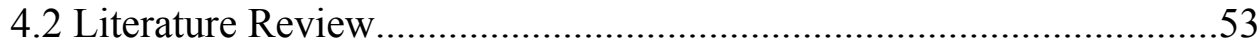

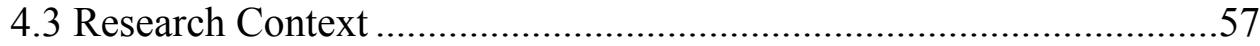

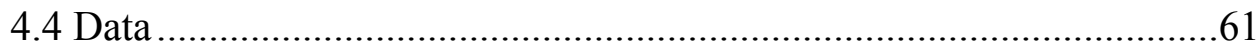

4.5 The Spatial Hedonic Pricing Models .................................................66

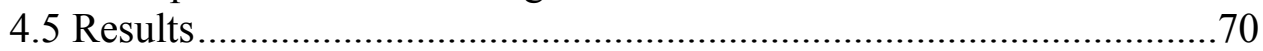

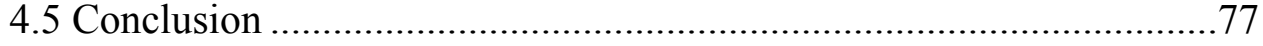

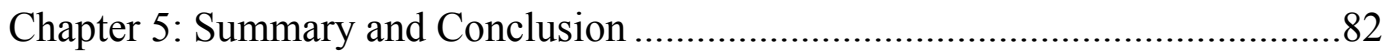

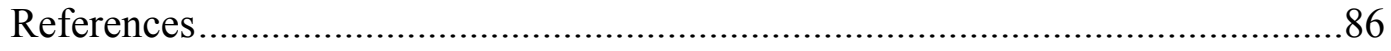




\section{List of Tables and Figures}

\section{Tables}

Table 1.1 Indicators of Housing Financial Market in Korea..............................3

Table 3.1 Trend of housing and related economic variables, 1975-2002 _........29

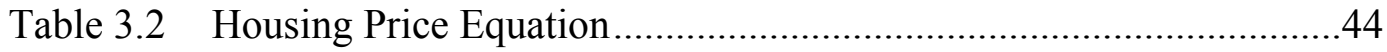

Table 3.3 Construction Equation .............................................................4

Table 4.1 Description and Summary Statistics of Variables ............................62

Table 4.2 Average growth rate of housing prices...........................................65

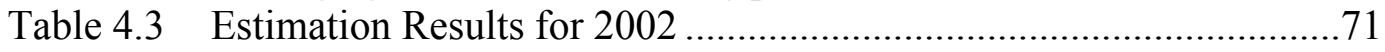

Table 4.4 Estimation Results for 2005 ........................................................... 72

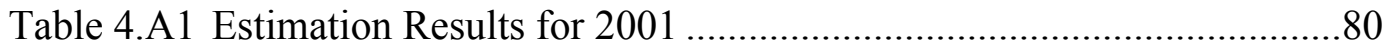

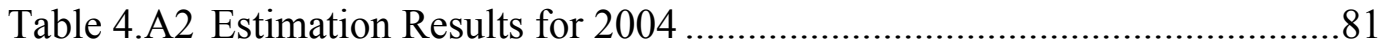

\section{Figure}

Figure 4.1 Areas of the New Town Project in Seoul ........................................59 


\section{Chapter I}

\section{Introduction, Brief Overview of Korean Housing Market and Dissertation Outline}

\subsection{Introduction}

This dissertation presents an analysis of the impact of government intervention on South Korea's housing market. There are many factors that determine housing decisions. In general, economic forces and shocks are distinguished between micro and macro factors. Micro forces in the housing market are the structural and locational factors that influence the value or use of one particular unit. Therefore, a microeconomic approach is involved in the study of the use, development, or pricing of individual properties. In contrast, macro forces are the broad economic factors that affect the behavior of the overall market, aggregating across individual properties.

Government policy is one of the key determinants of housing prices in the Korean housing market. Government regulations for land use originated in the 1970s in order to suppress speculation in housing and stabilize housing prices. Son (1994) and Hannah et al (1993), however, argued that land-use regulations contributed to increasing housing prices. Son and Kim (1998) presented evidence that urban land use controls are a main source of urban land shortage.

However, those studies analyzed the Korean housing market by the mid 1990s even though land supply has changed a lot from 1994. Furthermore, none of the literature addresses the following questions: Do land-use regulations affect housing prices by constraining housing construction or by stimulating housing demand? This dissertation attempts to address these questions by employing macroeconomic approaches. This 
dissertation also investigates whether housing markets anticipate the future effects of residential redevelopment by addressing spatial issues in the housing market. An overview of the Korean housing market is presented below.

\subsection{A Brief Overview of Korean Housing Markets}

Many housing market indicators provide evidence that housing is a key sector in the Korean economy in terms of its size, both in stock and in flow measures. Housing stock was estimated to be 36 percent of the nation's total capital stock in 1996 (Pyo, 1998). Housing investment, defined as the market value of the structure of new houses and improvements for existing houses, has made up 3 to 9 percent of GDP and 14 to 31 percent of total investment during the last three decades. Furthermore, housing prices and housing construction have been affected by macroeconomic variables such as income, interest rates, and inflation. For instance, housing prices collapsed following the financial crisis in 1997 and the recent increase in housing prices has been associated with low interest rates. Korea has undergone unprecedented economic growth during the last four decades. Per capita Gross National Product (GNP) grew from $\$ 69$ in 1960 to $\$ 12,720$ in 2003 in nominal terms. The population also increased from 25 million to 47.9 million and the number of households more than tripled during the same period. Swift urbanized has accompanied the rapid growth of the South Korean economy. Urban population rose from 35.8 percent in 1960 to 89.8 percent in 2003. It is widely believed that those socioeconomic forces have boosted housing demand. Table1.1 provides supportive evidence that house purchases have been an important purpose of savings even though it has decreased. 
Table 1.1

Indicators of Housing Financial Market in Korea

$\begin{array}{lllllllll}1996 & 1997 & 1998 & 1999 & 2000 & 2001 & 2002 & 2003 & 2004\end{array}$

(1) Purposes of Savings (\%)

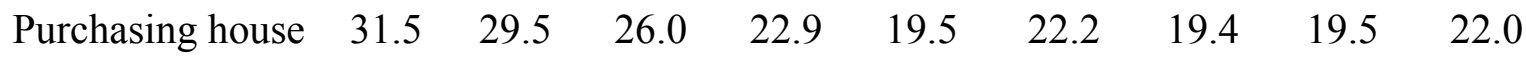

$\begin{array}{llllllllll}\text { Education } & 22.2 & 18.3 & 18.8 & 20.9 & 20.1 & 18.9 & 21.1 & 17.8 & 17.4\end{array}$

$\begin{array}{llllllllll}\text { Security } & 17.1 & 17.3 & 17.5 & 17.2 & 18.4 & 20.1 & 26.1 & 24.7 & 26.4\end{array}$

$\begin{array}{llllllllll}\text { Investment } & 15.4 & 14.5 & 13.5 & 13.6 & 13.1 & 11.8 & 9.9 & 11.6 & 9.8\end{array}$

(2) Loan-to-Value and Price-Income-Ratio (PIR, \%)

$\begin{array}{llllllllll}\text { Loan-to-Value } & 25.0 & 26.2 & 27.1 & 28.0 & 33.9 & 38.3 & 32.1 & 32.4 & 36.9\end{array}$

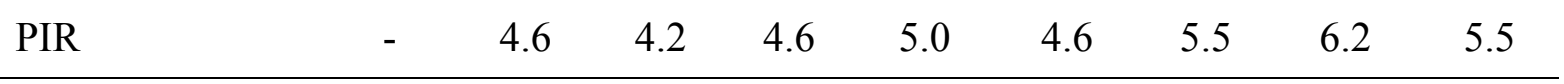

(3) Primary source of fund for purchasing own house

\begin{tabular}{lccccc}
\hline & 1987 & 1992 & 1997 & 2001 & 2004 \\
\hline $\begin{array}{l}\text { Savings } \\
\text { (including Chonsei) }\end{array}$ & 42.3 & 49.2 & 43.0 & 49.2 & 50.5 \\
$\begin{array}{l}\text { Inheritance and } \\
\text { Family Support }\end{array}$ & 44.6 & 40.5 & 36.2 & 29.3 & 26.7 \\
Loans & 8.7 & 6.4 & 16.1 & 16.7 & 19.1 \\
Sale of other assets & 2.9 & 2.6 & 2.5 & 2.5 & 1.6 \\
Others & 1.4 & 1.3 & 2.2 & 2.5 & 2.2 \\
\hline
\end{tabular}

(4) Housing Supply Ratio (\%)

\begin{tabular}{|c|c|c|c|c|c|}
\hline & 1960 & 1970 & 1980 & 1990 & 2000 \\
\hline Whole Country & 82.5 & 78.2 & 71.2 & 70.4 & 96.2 \\
\hline Urban Areas & 66.5 & 58.8 & 56.6 & 61.1 & 88.7 \\
\hline Rural Areas & 88.9 & 92.6 & 91.7 & 98.1 & 124.7 \\
\hline
\end{tabular}

Source: Kookmin Bank, Residential Financial Demand Actual Condition Investigation Results, each year. National Statistical Office, Social Statistics Survey, Census of Population and Housing, each year 
The Korean government regulated the housing financial market to support the economic development plan focusing on the export oriented industries the early 1990s. One government-supported institution dominated the Korean housing financial market. The Korea Housing Bank (KHB) issued the loans of 10 to 15 year maturity to higher income households and managed the National Housing Fund (NHF) providing below market loans to low-income households. However, the amount of the loans per household was limited so that the loan-to-value ratio was typically below 30 percent. Furthermore, only new houses were eligible for loans, and households with particular income or job profiles were given priority (Kim, 2004). Consequently, there was a lack of housing financial funds. According to Yoon (1995), financial institutions funded less than onethird of construction costs excluding the cost of land. Total housing loans outstanding amounted to 11.6 percent of the Gross National Product (GNP), as compared to 53.9 per cent in the United States (1993), 56.9 percent in the United Kingdom (1992), and 29.6 percent in Japan (1994). Due to lack of funds, the loan-to-value ratio was 30.9 per cent in 2002. The size of the primary market has increased substantially with financial deregulation in the early 1990s and privatization of KHB in 1997. According to Table 1.1, the loan-to-value ratio has increased from 25.0 percent in 1996 to 36.9 percent in 2004. The establishment of the secondary mortgage market in 1999 has contributed to improving the function of the housing financial market.

Government intervention in the financial sector has created a large informal, or curb, market. The sectors of the economy that cannot get credit through the formal financial market are financed by the curb market. According to the literature, the curb market's size has been estimated to range from 10 percent to 20 percent of Korea's GDP. 
In addition to the curb market, Korea has the Chonsei housing finance mechanism as a private financing means. It developed naturally in response to financial market constraints and housing shortages. Under this rental contract, the tenant gives the landlord a lump sum deposit in place of monthly rental payments. The deposit is held by the landlord during occupancy and is returned to the tenant when the dwelling is vacated. Because of the lack of funds, the Chonsei deposit serves as a financing source for the purchase of a house to the would-be landlord. Total Chonsei deposits in 1997 were estimated to be about twice as large as the total mortgage loans outstanding (Kim and Suh, 2002). Chonsei has become less important as a financing mechanism in recent years as monthly rental contracts and mortgage financing have become more popular than in the past.

Even though financial deregulation privatization has increased the size of the housing financial market, the housing financial market has not performed its intended function successfully. Table 1.1 shows that about 77-90 percent of homeowners finance purchasing their houses with their family support and savings (including Chonsei) while the ratio of homeowners financing by loans increased from 6.4 percent to 19.1 percent, in 1992 and 2004, respectively. Under these circumstances, borrowing constraints are clearly evident in the Korean housing market.

Since the supply of housing is fixed in the short run, housing prices are determined by housing demand that is affected by macroeconomic forces. Inflation is a key macroeconomic variable. While it is widely accepted that inflation affects housing price, housing price can be a leading indicator of inflation because supply is more responsive to demand in other goods markets. Therefore, it is claimed that housing price 
increases tend to provide useful information in predicting inflation. Kim (2004) provides evidence that the Consumer Price Index (CPI) and purchase price of housing appear to move together. He provides the results of Granger causality tests between housing price and the CPI. The test results suggest that the causality runs in both directions between housing price and CPI inflation. This implies that housing price not only is determined by inflation but also provides useful information on inflation.

Housing construction fluctuates in response to macroeconomic shocks as well as changes in housing market conditions. In addition to economic factors, government policy has been a major factor in determining the level of housing construction in Korea. During the early stage of development, government considered housing as a lower-return sector compared with manufacturing and export-oriented industries, and hence discouraged the nation's scarce capital from flowing into housing. However, government has used residential construction to counter economic fluctuations. Kim (2004) conducted a Granger causality test to see whether residential construction Granger causes GDP and whether GDP Granger causes residential construction. The result suggests that housing does not Granger cause GDP but follows the fluctuations of the general economy. It is widely alleged that government intervention in housing construction has resulted in housing shortages and hence high housing prices. It might be true until the government launched the Two Million Housing Construction Drive from 1988 to 1992. The ratio of housing stock to the number of households decreased by 1990 but jumped in 2000, which implies that government has recently responded to the problems caused by housing shortage. 
Of more importance is land-use regulation for residential construction in the Korean housing market. The evolution of land-use policy is helpful to understand a general picture of land-use regulations in the Korean housing market. Changes in demographic characteristics, rising income, growing economics activities, and rapid urbanization stimulated the demand for urban land which in turn raised housing prices. Son (1994) described the early stage of land-use policy. Korean construction firms who entered the Middle East construction market resulted in the substantial inflow of foreign exchange in the late 1970s. This increase in foreign exchange caused general inflation and a rapid increase in land prices. The most serious problem with rapidly rising land prices was speculation in housing. To suppress speculation and stabilize land prices, the Korean government enforced various measures including establishing the Korea Land Development Corporation (KLDC), a public land developer for residential land in 1978. Only public developers were allowed to engage in large scale land development. However, housing prices soared again in the 1980s. In order to solve the housing shortage problem, government initiated the Two-Million Housing Construction Drive of 1988 to 1992. It substantially contributed to stabilizing housing prices; housing price began to decrease in 1992. While land-use conversion is controlled by the Land Use Conversion Act, redevelopment within a city is restricted by the Urban Planning Act (UPA). Seoul, the capital of Korea, has announced the New Town redevelopment recently based on UPA. For these reasons, the Korean housing market can be affected by government policies as well as market forces. 


\subsection{Dissertation Outline}

This dissertation consists of four research chapters. Chapter 2 describes an overview of the stock-flow model and develops a theoretical model for the Korean housing market. The remainder of this dissertation is organized as follows: Chapters 3,4 , and 5 present the three research essays. Chapter 6 provides a brief summary and conclusion.

Chapter 2 provides a clearer picture of how various macro forces affect housing prices and rent by dividing the housing market into two types: the market for housing services and the housing capital market. Even though the rent is determined in the market for housing services and the function of the market for housing capital is to determine housing price, the stock-flow model can be used to link these two markets and to investigate the effect of a variable on the two markets. Therefore, the stock-flow model is used to analyze aggregate models of housing market. Following an extensive review of studies, Chapter 2 also develops the theoretical stock-flow model for the Korean housing market. This model provides the theoretical background for an analysis of the following question: how do land-use regulations affect housing prices?

In Chapter 3, two econometric models are used to find whether land-use regulations constrain construction which in turn raises housing prices or whether they stimulate the demand for housing through expectation of future housing prices. Given the information of land supply for residential construction, the people can expect the future housing prices based on the flow of land supply. Therefore, the expectation about land supply is incorporated into the demand equation. The land supply variable is also 
included in the construction equation because housing construction depends on the amount of available land.

The empirical examination reveals that land-use regulations have binding effects on housing production. Even though these results are consistent with the argument provided by the early literature, this chapter extends the analysis scope to demand side. The expectation about a shortage of land supply spurs the current demand, which in turn leads to higher housing prices. The results suggest that land-use regulations raise housing prices by increasing investment demand for housing. The results also suggest that borrowing constraints are present in the Korean housing financial market and it should be incorporated into the stock-flow model. Finally, it is demonstrated that government intervention into owner-occupied construction has contributed to escalating the speed at which the stock adjusts to an equilibrium.

Chapter 4 employs a micro approach to analyze the impacts of inner-city redevelopment on housing prices. The Seoul metropolitan government announced the New Town redevelopment project to revitalize distressed areas in 2002 and 2003. Since the extensive land redevelopment project leads to significant change in residential neighborhoods, it generates spillover effects on the values of housing units located in close proximity. In addition, this redevelopment project is undertaken based on mixed land uses against the urban sprawl problems. Different type of mixed land uses generates the different effects. A spatial hedonic housing price model is used to estimate and measure the spillover impacts of redevelopment with different mixed land uses on surrounding housing prices. Another purpose of this research is to explore whether housing markets anticipate the future spillovers of the completed project. 
The findings suggest that neighborhood spillovers of redevelopment depend on the distance from the New Town redevelopment area and the type of mixed land uses. The test results of a pre-post approach suggest that the change in housing prices takes place the year the announcement was made, which implies that housing markets have begun to anticipate the future effects of the completed project. 


\section{Chapter 2}

\section{Overview of The Stock-Flow Model}

The housing market actually consists of two markets: one for the stock of housing capital, which determines the price of houses, and another for the flow of housing services, which determines the implicit or explicit rent. Shocks on either of these markets can affect house prices because the two markets are linked through the rent levels. Aggregate models of the housing sector largely evolved during the 1960s. Much of the literature focused on forecasting the level of new residential construction (Alberts 1962, Brady 1967, Maisel 1963). The analysis gradually shifted to the owner-occupied housing sector by investigating price movements and the role of financial institutions or credit markets. Specification of demand and supply equations contributed to more complete models. Most of the early literature examined part or some variation of a basic stock-flow model of the housing sector which consists of demand and construction equations. (Dipasquale and Wheaton, 1994)

As the early literature indicates, the stock-flow model is used to analyze aggregate models of housing market. It is important to explicitly recognize the relationship between stock and flow behavior. Dipasquale and Wheaton (1996) describe how both the property and housing capital markets operate. The housing market can be distinguished between the market for housing services where housing is rented or purchased for occupancy and the market for housing capital where buildings are bought and sold as investments. The housing stock basically provides the flow of housing services which determines the rent. At the same time, the housing stock may be bought, sold, or exchanged between 
investors. These transactions occur in the capital market and determine the price of houses. This chapter describes a simple analytic framework that illustrates the connections between the market for housing services and the market for housing capital. The distinction between the market for housing services and the market for housing capital helps to clarify how different forces influence housing markets.

\subsection{The Market for Housing Services}

In the property market, the flow of housing services is determined by the housing stock, $S$. It is assumed that the flow of services from the fixed housing stock is inelastically supplied in the short run. Therefore, the demand for housing services determines the implicit or explicit rent, $R$, that is assumed to clear the property market by rationing demand to the fixed stock. The demand for housing services depends on rent, income levels, $Y$, and demographic factors such as the number and characteristics of households, $H H$. The function of the market for housing services is to determine a rent level at which the demand for housing services equals the supply of housing.

The traditional stock-flow model assumes that markets clear quickly and, at any time, prices adjust and equate the demand for housing with the existing stock which provides housing services, Equation (2.1):

$$
D(R, Y, H H)=S
$$

\subsection{The Market for Housing Capital}

Since the housing stock is also an asset, investors earn a current or future income stream when they acquire housing. Thus, changes in rent occurring in the property market 
immediately affect the demand for ownership in the asset market. Therefore, the rent levels determined in the market for housing services are central in linking the property market and the market for housing as an asset. Furthermore, the asset market equilibrium requires the rent to be equal to the user cost of owning housing in a perfect financial market

$$
R=H P \cdot U
$$

where HP is the price of house and $\mathrm{U}$ is the user cost of homeownership. The market for housing services is directly related to the market for housing stock through the relationship between the rent and the user cost of homeownership. Even though it is now widely accepted that the effective user cost of housing assets is affected by interest rates, inflation, and tax policy, the financial user cost of homeownership considered only mortgage interest rates before the 1980s.

Kearl (1979) first introduced the definition of the user cost of homeownership. The correct measure of user cost of homeownership should be an after-tax cost of debt and property taxes.

$$
U=\left(i+t^{p}\right)\left(1-t^{y}\right)+d-\dot{H} P
$$

where $i$ is the nominal mortgage interest rate, $t^{p}$ is the property tax rate, $t^{y}$ is the marginal income tax rate, $d$ is the rate of depreciation and maintenance costs, and $\dot{H P}$ is the expected annual rate of future price appreciation.

Much of the literature analyzed the effects of inflation on the demand for housing in the early 1980s. It was widely believed that inflation creates a variety of different effects even if inflation is perfectly anticipated. First, inflation raises initial mortgage payments through higher nominal interest rates. Second, it shortens the maturity which 
stimulates the demand for housing. Finally, it causes a real growth in housing equity. Kearl (1979) and Follain (1982) showed that the sum of these impacts reduced housing demand. On the other hand, Dougherty and Van Order (1982) and Poterba (1984) suggested that inflation reduces the after-tax user cost of homeownership which in turn increases the demand for owner-occupied houses. According to their conclusions, inflation stimulates housing demand since it reduces the effective cost of homeownership and raises the tax subsidy to owner occupation. Higher inflation rates not only raise the homeowner's mortgage payments through pushing up nominal interest rates but also result in greater nominal capital gains on houses. In general, the tax system permits homeowners to deduct mortgage interest payments from their taxable income and tax is not imposed on capital gains on houses. Therefore, an increase in the inflation rates reduces the real cost of homeownership, which in turn increases the demand for housing and real housing prices. Schwab (1982) concluded that in a perfect capital market, fully anticipated inflation should not create distortion in housing consumption. Dougherty and Van Order (1982) and Schwab (1982) analyzed the effects of inflation on housing demand by developing Fisher-type models of intertemporal utility maximization. They argued that imperfect capital markets must be assumed to explain the empirical results. However, they did not clarify what kinds of constraints exist in a capital market. Wheaton (1985) extended the Fisher model to a continuous life-cycle model to clarify the results of Schwab (1982). He incorporated two liquidity constraints and borrowing constraints to examine the impacts of inflation on the demand for housing. Wheaton (1985) suggested that the effects of inflation on housing demand depends on how each constraint works. If liquidity constraints prohibit borrowing against future earnings, but allow borrowing 
against accumulating housing equity, there is a positive relationship between housing demand and inflation. However, borrowing constraints produce a negative impact on housing demand only when the constraints are binding and only when real interest rates are less than consumer discount rates.

During the 1980s, the U.S. tax laws underwent dramatic restructuring which resulted in lower marginal tax rates. The new tax systems was expected to reduce the distortionary impact of the deductions (Follain and Ling, 1991). Much of the literature began to analyze the impacts of these tax reforms on the user costs of owning houses, rents, and homeownership. Ceteris paribus, these reforms should have raised the after-tax user costs of homeownership which in turn reduce the demand for owner-occupied housing. Poterba (1991) provided the evidence that tax changes played an important role in explaining changes in user costs during the 1980s. Van Order and Dougherty (1991) concluded that the real user costs of homeownership are the most important factor in housing demand. More recently, Green and Vandell (1999) demonstrate that the tax deductibility of mortgage interest and property taxes by homeowners in the U.S has a considerable effect on homeownership.

The correct measure of the user cost needs to specify a process by which consumers form expectations about future housing price appreciation. Clark (1995), Capozza and Seguin (1996), and Clayton (1997) adopted the theory of rational expectations. Rational expectations assume that forward forecasts use all the information available about a market's operation. More formally,

$$
\dot{H P}=\frac{H P_{t+1}^{e}-H P_{t}}{H P_{t}}
$$


where $H P_{t+1}^{e}$ is the expected value of housing one year from now. If the market forms house price expectations rationally then $H P_{t+1}^{e}$ is mathematically defined as the expectation of the one-year ahead conditional on all current and past information,

$$
H P_{t+1, t}^{e}=E_{t}\left[H P_{t+1} \mid I_{t}\right]
$$

where $I_{t}$ is the information set available to agents in period $t$. This condition states that agents have complete knowledge about the structure of the model driving house price movements, complete knowledge of the parameters, and complete knowledge of all current and past values of the variables in the model. This implies that realized house prices differ from expected values by only a random error,

$$
H P_{t+1}=E_{t}\left[H P_{t+1} \mid I_{t}\right]+\varepsilon_{t+1}
$$

Clayton combines equations (2.2) through (2.6) to generate an expression for the one year ahead housing price prediction,

$$
E_{t}\left[H P_{t+1} \mid I_{t}\right]=\left[1+\left(i_{t}+t_{t}^{p}\right)\left(1-t_{t}^{y}\right)+d_{t}\right] H P_{t}-R_{t}
$$

Clayton argues that under the assumption of rational expectations and the asset market equilibrium condition (2.2), housing price expectations depends on current markets data on housing prices, rents, and other exogenous variables. Ceteris paribus, expected future housing prices are positively related to current housing prices and negatively related to current rents.

Clark (1995) and Capozza and Seguin (1996) use the rent-price ratio to examine whether variations in housing prices and rents are consistent with the rational expectations. They found that the rational expectations appear to be important in variations in housing prices and rents over long periods. 
An alternative approach is to model directly the formation of expectations based on some pattern of current or past behavior in the market. While backward-looking expectations models are frequently criticized as being ad hoc, much of the literature shows that consumers frequently behave in this manner. Case and Shiller (1989) showed that the short run movements in house prices tend to be followed by movements in the same direction in the subsequent year. Mankiw and Weil (1989) provided strong evidence of irrational expectations. They claim that housing prices respond too much to current changes in housing demand and too little to future changes in housing demand predictable from current demographics. According to backward-looking expectations, the expected rate of house price appreciation in each period is related to current or past price movements. The expected price appreciation could be assumed to be equal to a moving average of recent price appreciations,

$$
\dot{H P}=E\left[\frac{\Delta H P_{t}}{H P_{t}}\right]=\left(\frac{H P_{t-1}-H P_{t-n}}{H P_{t-n}}\right)^{1 / n}-1, \quad n>1
$$

Furthermore, Peng and Wheaton (1994) incorporate the rate of land supply into price expectations in the case of restrictive residential land supply. Since an unexpected scarcity of future developable land reduces housing construction which in turn drives up housing prices, the expected scarcity of land directly alters the expectation about future housing price appreciation. Therefore, with backward-looking expectations, the expected rate of future house price appreciation is assumed to depend on two kinds of information. Consumers tend to look at recent rates of house price appreciation and recent land supply to adjust their expectations,

$$
\dot{H P}=g(\dot{H P A}, \dot{L S})
$$


where $\dot{H P A}$ is the rate of recent house price appreciation and $\dot{L S}$ is the rate of recent land supply for housing construction.

It has been widely perceived that borrowing constraints are present in the Korean housing financial market. Park and Kim (1999) provide supporting evidence that the amount of loan from financial institutions for purchasing houses is only about 28 percent of house price. The rest of house price is financed by such other sources as a gift from the family or other savings. It seems likely that the financing sector of the housing market has not performed its function successfully. Therefore, the asset market equilibrium does not hold in the case of the Korean housing market.

In addition, land development for residential construction is strictly restricted in Korean housing market. The basic purpose of land-use regulations is to suppress real estate speculation which dramatically raises housing prices. There are three kinds of landuse regulations in the Korean housing market. Even though a city grows, land conversion from the rural to urban use is performed by only government-supported developers. There is Green-belt policy which was legislated to preserve the urban environment. Son and Kim (1998) provided the empirical results that green belts are one of the main reasons of urban land shortage. Zoning policy also restricts the land use for housing construction.

As long as those strict land-use regulations exist, land-use regulations affect not only housing construction but also the demand for housing through the expected price appreciation from land supply. That is, consumers expect changes in land supply provided by a government to directly influence current or future housing prices. If a government complete control over land supply for housing construction without any 
long-run land supply schedules, a decrease in land supply can constrain future housing construction which in turn raises housing prices in the future. It stimulates the current demand for housing and leads to higher current housing prices. In the case of increase in land supply, the opposite results are expected to be obtained. Therefore, it could be the case that there is a negative relationship between the price of house and the expectation of land supply if land supply for housing construction is restricted by a government.

With all factors taken into consideration and under the assumption of backwardlooking expectations, the demand for housing asset is assumed to be equal to the existing stock in am imperfect financial market,

$$
D(Y, H P, R, U C O, \dot{L} \dot{S}, H H)=S
$$

where UCO is $\left(i+t^{p}\right)\left(1-t^{y}\right)+d-g(\dot{H P} A)$. Solving Equation (2.11) for current house price yields the following:

$$
H P=f(S, Y, H P, R, U C O, \dot{L S}, H H)
$$

Equilibrium house price levels are determined in each period as a function of the housing stock, demand forces, and the rate of recent land supply for housing construction.

\subsection{Construction}

A series of equations should be used to explain the durable housing stock. The dynamics of the stock depends on the difference construction, $\mathrm{CO}_{t}$, and demolition of the previous period's stock, $\delta S_{t-1}$,

$$
S_{t}-S_{t-1}=C O_{t}-\delta S_{t-1}
$$


Equation (2.13) states that the stock will increase as long as construction exceeds demolitions, and decrease if the opposite is true. When construction exactly equals replacement needs, the stock is said to be in a stable steady state (Dipasquale and Wheaton, 1996).

The traditional construction models specify construction as a function of only cost factors. An increase in costs results from bottlenecks in the short run and from increasing supply schedules for labor and raw materials in the long run. Therefore, a long run increase in house price levels causes a permanent increase in the flow of construction. However, this kind of traditional construction model does not incorporate land into construction equation. More recent spatial literature has showed that land and land prices are determined by the stock of housing rather than the flow of construction. (Wheaton, 1982 and Braid, 1988) The rise in house price leads to excess returns which in turn increase construction. As the stock of housing grows due to new construction, land prices rise and eventually absorb excess returns. Construction, hence, falls to its normal level. This kind of model specifies that house price level determines the long run stock of housing. House price level, however, influences construction only temporarily until the actual stock catches up to the long run equilibrium stock, $S_{t}^{*}$, which is determined at the edge of city where land price equals agriculture rent (Dipasquale and Wheaton, 1994).

Therefore, construction clearly will depend on the current level of house prices, cost shifters, and the stock of units. Dipasquale and Wheaton (1994) specify the following model of construction:

$$
C O_{t}=\tau\left(S_{t}^{*}-S_{t}\right)
$$


where $\tau$ represents the speed with which the stock adjusts through new construction. If the actual current stock, $S_{t}$, is equal to the long-run equilibrium stock, $S_{t}^{*}$, no construction occurs. Even though an increase in house price raises construction, it is temporary until the actual housing stock catches up to the long-run stock determined by rent theory. It is widely held opinion that much of new construction of the single family housing has occurred at the edge of more rapidly growing cities in the United States (Dipasquale and Wheaton, 1996).

The decision to construct housing units is based on the profit opportunity as reflected in the difference between housing price and construction costs. If housing price exceeds construction costs, more housing units will be built. With respect to construction costs, land supply is one of key determinants of construction costs in the case of land-use restriction for housing construction. Such regulations may create a scarcity of land. This can drive up land prices and hence raise land development costs. The more binding or restrictive such regulations become, the more they increase development costs. This increase in costs will reduce construction operation. Therefore, it is important to investigate whether land-use restriction has a binding effect on construction.

Because of the long run duration of constructing tall residential buildings, current housing completion must be a result of previous period's decision. Construction is a function of lagged housing prices, lagged construction cost factors, and the rate of recent land supply,

$$
C O_{t}=h\left(H P_{t-1}, X_{t-1}, \dot{L S_{t-1}}\right)-\tau S_{t-1}
$$

where $X$ is a vector of construction cost factors. 


\subsection{Steady-State Solution and Elasticity}

Change in the stock is the difference between construction and demolition of the previous period's stock. If the price is too low, construction is not sufficient to replace the demolished units. This will decrease the stock which raises housing prices through Equation (2.12). Higher housing prices will induce new construction high enough to exceed replacement, which in turn increases the stock. The reverse is also true. Given fixed values for the exogenous variables in the model, there is always one value of the stock at which housing price generates just enough new construction to sustain that value of the stock. This stock, $S^{*}$, and the associated housing price, $H P^{*}$, are the model's full steady-state solution (Dipasquale and Wheaton, 1996).

With the assumption of a linear demand function, the market clearing equation (2.11) at a steady state becomes:

$$
\alpha_{0}+\alpha_{1} H P^{*}+\alpha_{2} Y+\alpha_{3} R+\alpha_{4} U C O+\alpha_{5} \dot{L}+\alpha_{6} H H=S^{*}
$$

$H P^{*}$ can be obtained from rewriting Equation (2.16):

$$
H P^{*}=\frac{1}{\alpha_{1}}\left[S^{*}-\left(\alpha_{0}++\alpha_{2} Y+\alpha_{3} R+\alpha_{4} U C O+\alpha_{5} \dot{L} S+\alpha_{6} H H\right)\right]
$$

With respect to $S^{*}$, combining Equations (2.13) and (2.14) at a steady state yields:

$$
C O=\delta S
$$

In assuming a linear construction function, combining Equations (2.15) and (2.18) and rewriting yield as follows:

$$
S^{*}=\frac{\beta_{0}+\beta_{1} H P+\beta_{2} C C+\beta_{3} i+\beta_{4} \dot{L S}}{\delta+\tau}
$$


Equation (2.19) implies that the long run steady-state stock moves as a function of housing price even though the stock is fixed in the short run. The simultaneous system of two equations (2.17) and (2.18) must be solved for $S^{*}$ and $H P^{*}$. This simultaneous solution to the equations gives the long run equilibrium price and stock that will prevail in the market if today's exogenous variables hold forever. However, the long-run, steadystate equilibrium is affected by changes in exogenous variables. Therefore, the impacts of exogenous variables on housing prices discussed in the previous sections can be obtained by comparative statics analysis in Equations (2.17) and (2.19).

Since the market for housing services is related to the market for housing capital, any shock to any market affects both rents and house prices. However, the magnitude of these changes will depend on the elasticities.

The price elasticity of demand can be derived from Equation (2.16):

$$
\frac{\partial D}{\partial H P} \frac{H P}{D}=\alpha_{1} \frac{H P}{D}
$$

The price elasticity of supply in a long run steady state can be derived from Equation (2.19):

$$
\frac{\partial S^{*}}{\partial H P} \frac{H P}{S^{*}}=\frac{\beta_{1}}{\delta+\tau} \frac{H P}{S^{*}}
$$

The price elasticity of supply in a long steady state can be obtained in another way. Differentiating (2.16) with respect to house price and rewriting yield

$$
\frac{\partial C O}{\partial H P} \frac{H P}{C O}=\frac{\partial S^{*}}{\partial H P} \frac{H P}{S^{*}}
$$

Therefore, in a long run steady state, the price elasticity of construction must be equal to the price of elasticity of stock. 
One implication of a stock adjustment process is that the adjustment rate, $\tau$ reflects the average ratio of investment-to-stock ( $\mathrm{CO} / \mathrm{S}$ ). Differentiating the construction equation (2.14) with respect to house price yields

$$
\frac{\partial C O}{\partial H P}=\tau \cdot \frac{\partial S^{*}}{\partial H P}
$$

Rewriting Equation (2.18),

$$
\frac{\partial C O}{\partial H P} \frac{H P}{C O}=\left(\frac{\tau S}{C O}\right) \cdot \frac{\partial S^{*}}{\partial H P} \frac{H P}{S}
$$

Since the price elasticity of construction must be equal to that of supply in the long run steady state, $\tau$ should be equal to S/CO for Equation (2.19) to hold. 


\section{Chapter 3}

\section{Land-Use Regulations and the Housing Market in the case of Korea}

\subsection{Introduction}

Since the South Korean government adopted an export-oriented economic development strategy in the early 1960s, it has experienced unheard-of economic growth. Per capita Gross National Product (GNP) grew from \$69 in 1960 to \$10,013 in 2002 in nominal terms. Population also increased from 25 million to 47.6 million and the number of households more than tripled during the same period. Swift urbanization has accompanied the rapid growth of the South Korean economy. Urban population rose from 35.8 percent in 1960 to 89.3 percent in 2002 .

While demand-side factors provided a strong impetus to rapidly rising housing prices, the government placed low priority on housing markets by investing more resources into industrial development and infrastructure construction prior to the late 1980s. Housing prices jumped dramatically in the late 1980s. In order to reduce housing prices, the government has been extensively involved in the housing market with rigid regulations to suppress property speculation. The government also controlled the supply side with price controls on new apartments and various rigid restrictions on land use. Since the Land-Use Conversion Act was legislated in 1980, the government has monopolized land conversion from rural to urban. Furthermore, the government has played a dominant role in supplying new housing units. On average, public housing construction is 38 percent of total annual housing construction on annual average from 1972 to 2002. 
Many studies on the Korean housing market claimed that rigid regulations were attributable to a shortage of housing supply which in turn drove up housing prices as socioeconomic factors induced the great increase in housing demand. Hannah et al (1993) and Kim (1993) argue that a shortage of land supply for housing production is the key reason for inelastic housing supply which could not keep pace with a strong demand stimulated by socioeconomic factors in South Korea. Son and Kim (1988) present estimates of the measures of shortage or surplus for Korean cities. They found shortages of land in the six largest cities and cities in Kyunggi province adjacent to the capital of Korea. According to their examination, land-use regulations are the dominant cause of urban land shortages. Kim and Kim (2000) show that the government's risk-averse behavior prevents land-use regulations from being relaxed. Since the public believes that deregulation of land-use controls results in serious land speculation, which drives up land prices and housing prices, government officials are worried about the political consequences of their decisions. Even though much of the literature has studied the impact of land-use regulations on the Korean housing markets, no empirical literature analyzes the mechanism by which land-use regulations exert an impact on housing production and housing prices. Furthermore, most studies focusing on land-use regulations and the housing market were undertaken prior to the mid 1990s. However, the government has played a critical role in providing land for housing production and building housing units since the late 1980s. Therefore, it is important to extend the time period of analysis to investigate the impacts of land-use regulations on the Korean housing market. 
Peng and Wheaton (1994) follow a time-series approach to analyze how a scarcity of land supply affects housing markets in Hong Kong. They incorporate land supply into both housing demand and construction equations in order to determine whether land supply restrictions raise housing prices because of inhibited housing construction or because of higher investment demand stimulated by expected rising future rents. They demonstrate that a shortage of land supply exerts a direct effect on higher housing prices through expected higher future rents rather than a reduction of housing production. Their result implies that restrictions on land supply do not reduce the production of housing units because of the Hong Kong government's flexible building regulations.

The model presented in this paper is a variation of the model of Peng and Wheaton (1994) and is used to analyze the impacts of land-use regulations on Korean housing markets. Investors could not obtain high returns on financial assets because the government controlled the interest rate until 1995. In addition to the undeveloped financial market, the Korean unique rental system and borrowing constraints require the assumption of imperfect financial markets. The ratio of housing stock to the number of households is one of the determinants the government considers to devote land for housing production purposes. It has also been deeply involved in construction of owneroccupied housing. Therefore, it could be useful to examine the speed with which the stock adjusts through new construction. The model shows that a shortage of land supply from land-use regulations does not have a binding effect on housing construction but boosts investment demand, which in turn raises housing prices. 
The next section describes the characteristics of the Korean housing market and land-use regulations to review the role of government policy. Section 3 specifies the model. In section 4 and 5, data and variables are defined and empirical analysis is presented. Section 6 concludes the paper.

\subsection{Korean Housing Market}

\subsubsection{Characteristics of Korean Housing Market}

Table 3.1 presents housing price and related series from 1975 to 2002. The data shows that housing prices (HP), together with land prices (LP) rose faster than real income and general inflation. An annual growth rate of the national housing price index was 9.35 percent which is higher than that of the consumer price index (CPI), 7.45 percent, and that of real GDP, 6.38 percent. In the mid-1980s, the supply ratio $^{1}$ (SR) declined to less than 70 percent, which was mainly due to rapid urbanization and insufficient investment in housing production.

In 2002, the national housing stock (S) was 2.6 times its 1975 level. The annual growth rate of construction $(\mathrm{CO})$ was 10.39 percent during the same period. The Korean government was involved in the housing market during the same period. Public construction for owner-occupied housing was 38 percent of total owner-occupied housing construction between 1975 and 2002. However, the government was reluctant to accommodate the rapid increase in housing demand prior to the middle 1980s. For example, the housing industry built 220,000 houses annually, roughly 130,000 units short of the estimated annual need. The shortage of housing units in the mid-1980s led the

\footnotetext{
${ }^{1}$ The housing supply ratio is calculated as the number of housing units divided by the number of households.
} 
Table 3.1

Trend of housing and related economic variables, 1975-2002

\begin{tabular}{|c|c|c|c|c|c|c|c|}
\hline & $\begin{array}{c}\text { Housing } \\
\text { Price Index }\end{array}$ & CPI & GDP & $\begin{array}{l}\text { Stock of } \\
\text { Housing }\end{array}$ & Construction & $\begin{array}{l}\text { Land Price } \\
\text { Index }\end{array}$ & $\begin{array}{c}\text { Supply } \\
\text { Ratio }\end{array}$ \\
\hline $1975^{\mathrm{a}}$ & 100 & 100 & 100 & 100 & 100 & 100 & 74.4 \\
\hline 1976 & 127 & 115 & 111 & 102 & 91 & 127 & 73.3 \\
\hline 1977 & 158 & 127 & 122 & 104 & 113 & 169 & 72.6 \\
\hline 1978 & 206 & 145 & 133 & 107 & 151 & 252 & 72.5 \\
\hline 1979 & 285 & 172 & 143 & 110 & 127 & 294 & 72.0 \\
\hline 1980 & 361 & 221 & 140 & 112 & 95 & 328 & 71.2 \\
\hline 1981 & 438 & 269 & 149 & 115 & 91 & 353 & 70.5 \\
\hline 1982 & 448 & 288 & 160 & 119 & 127 & 372 & 70.2 \\
\hline 1983 & 550 & 298 & 177 & 124 & 145 & 440 & 70.2 \\
\hline 1984 & 566 & 305 & 191 & 128 & 121 & 499 & 70.1 \\
\hline 1985 & 566 & 312 & 204 & 129 & 112 & 534 & 69.8 \\
\hline 1986 & 551 & 321 & 226 & 133 & 132 & 572 & 69.7 \\
\hline 1987 & 590 & 330 & 251 & 136 & 78 & 657 & 69.2 \\
\hline 1988 & 668 & 354 & 277 & 141 & 186 & 837 & 69.4 \\
\hline 1989 & 765 & 374 & 294 & 149 & 267 & 1105 & 70.9 \\
\hline 1990 & 927 & 406 & 320 & 155 & 397 & 1332 & 72.4 \\
\hline 1991 & 921 & 444 & 350 & 166 & 360 & 1502 & 74.2 \\
\hline 1992 & 876 & 472 & 369 & 182 & 336 & 1483 & 76.0 \\
\hline 1993 & 851 & 494 & 389 & 186 & 440 & 1374 & 79.1 \\
\hline 1994 & 850 & 525 & 421 & 193 & 365 & 1366 & 83.5 \\
\hline 1995 & 848 & 549 & 459 & 202 & 359 & 1374 & 86.0 \\
\hline 1996 & 861 & 576 & 490 & 214 & 325 & 1387 & 89.2 \\
\hline 1997 & 878 & 601 & 514 & 224 & 332 & 1391 & 92.0 \\
\hline 1998 & 769 & 647 & 480 & 230 & 149 & 1202 & 92.4 \\
\hline 1999 & 796 & 652 & 532 & 236 & 208 & 1237 & 93.3 \\
\hline 2000 & 799 & 667 & 582 & 242 & 237 & 1245 & 96.2 \\
\hline 2001 & 878 & 694 & 600 & 251 & 300 & 1262 & 98.3 \\
\hline 2002 & 1022 & 713 & 638 & 261 & 408 & 1375 & 100.6 \\
\hline
\end{tabular}

Source: Housing and Commercial Bank, Economic Statistics Year-book,1996; Korea National Housing Corporation, Yearbook of Housing Statistics, 2003.

Note: All variables, except supply ratio, are computed as the index; the base year is 1975 . 
government to launch the Two Million Housing Construction Drive. In order to build two million housing units over a five-year period, which was equal to one-third of the existing housing stock in 1987, the government built five new towns in the Capital region and developed new land in other metropolitan areas as part of residential land supply measures. Since the government began to build two million houses, the annual growth rates of the housing stock and housing construction were 4.45 and 18.7 percent, respectively, from 1988 to 2002 , compared to 2.61 and 0.86 percent during the 1975 1987 period.

The poor performance of the formal housing finance system is one of the characteristics of the Korean housing market. The main reason is that the lending institutions do not have an adequate source of stable long-term funds. Until recently, Koreans could not rely on financial institutions to provide adequate housing loans when they purchased a home. Sources of housing loans were limited to the National Housing Fund (hereinafter the NHF) and the loans issued by the Korean Housing Bank (hereinafter KHB) ${ }^{2}$. The NHF, a government fund managed by the KHB for a fee, is restricted to subsidized low-interest loans to builders of small houses, which are then assumed as homebuyers once they move into the houses. The KHB was fully owned by the government with a mandate to allocate at least 80 per cent of its lending funds to housing loans by 1997. It has played a dominant role in financing private sector housing.

Yoon (1995) demonstrated that financial institutions funded less than one-third of construction costs excluding the cost of land. Total housing loans outstanding amounted to 11.6 percent of the Gross National Product (GNP), as compared to 53.9 percent in the

\footnotetext{
${ }^{2}$ KHB was privatized and renamed as the Housing and Commercial Bank in 1977. It merged with Kookmin Bank and was renamed again as Kookmin Bank in 2002.
} 
United States (1993), 56.9 percent in the United Kingdom (1992), and 29.6 percent in Japan (1994). Due to lack of funds, the loan to value ratio was 30.9 percent in 2002. The rest of the purchase price had to come from other savings, loans from other sources, a gift from the family, and a returned Chonsei deposit, a rental arrangement that is peculiar to Korea. Under the Chonsei arrangement, the tenant makes a deposit to the landlord at the time of occupancy. The deposit is held by the landlord during occupancy and is returned to the tenant when the dwelling is vacated. Defaults on Chonsei contracts are extremely rare because the tenant cannot occupy the dwelling until Chonsei is paid and needs not move out until it is returned. Chonsei is invested by the landlord, often in the purchase of the dwelling, and the actual or imputed return on the investment represents the rental for the part of the dwelling occupied by the tenant. Chonsei is an annual contract; the landlord typically demands an annual increase in the Chonsei deposit, as housing prices rise. In Korea, pure rent payment contracts and combinations of rents and Chonsei can also be negotiated. Kim and Mills (1988) have shown that rent is typically capitalized into Chonsei deposits at about the curb market interest rate. The curb market is an informal market for unsecured loans.

The choice among Chonsei and rent or Chonsei-rent contracts depends mainly on the relevant asset and liquidity positions of landlords and tenants. The lowest-income families typically have pure rental contracts. Families with higher incomes and more assets choose larger fractions of Chonsei and smaller fractions of rent. Many middle and upper-middle income families make their first home purchase by paying part of the purchase price from their accumulated assets and part from Chonsei returned from a rental dwelling they vacate. It is remarkable that it is still nearly impossible to take out a 
substantial mortgage secured by an owner-occupied house in Korea, except for a small minority of first-time buyers who obtain modest mortgages from the government housing bank. 54.2 percent of Korean families are owner-occupiers in 2000. Obviously, the financing sector of the housing market has not performed its intended function successfully.

\subsubsection{Korean Land-Use Regulations}

The nation was preoccupied with increasing land prices associated with the rapid economic growth and growing population before the mid-1970s. It was a widely held opinion that many speculators who had access to information on development accelerated land price increases in the absence of appropriate policy measures. The public began to call for land policy measures to stabilize land markets. Therefore, Korea's land policy has evolved with the presumption that government intervention is necessary for antispeculation in land markets.

Land use has been strictly restricted by three major categories of regulations.

First, national land use has been classified by the National Land Use Management Act (NLMA). NLMA confines the availability of land supply for housing construction. Even though the government relaxed NLMA in 1994 in order to make more suitable land available for construction, the share of residential land as a percentage of all urban land has been almost constant, 11.5 percent in 1973 and 11.9 percent in 2002. This is in sharp contrast to an increase in urbanization.

Secondly, the government legislated the Land Use Conversion Act (LUCA) which gives the government the authority of converting rural use to urban use. Under 
LUCA, land needed for various purposes is supplied within the framework of the national land-use plan prepared by the Ministry of Construction (MOC). MOC estimates the amount of land needed for each category of use based on projections of the size and spatial distribution of population and economic activities, and arranges for development of the land. MOC also provides land-use conversion and issues permits exclusively to public-sector agencies to prevent private developers from collecting a large windfall gain. Consequently, large-scale land development projects are virtually monopolized by the public sector, comprising the Korea Land Corporation (KLC), the Korea National Housing Corporation (KNHC), and local governments. They purchase sizeable tracts of raw land at appraisal prices, service them with infrastructure, have them rezoned as residential and commercial sites, and then sell out the developable land to home-builders. Under this system, houses get built in response to increased demand as long as the government increases the supply of developable land. This practice places a strict limit on the variety of developed land in terms of location, size, or pricing. There is also no room for a market for developed land that will respond to changes in the level and composition of the demand for urban land.

The last land-use regulation is a Green-Belt policy which was legislated in 1971 to restrain the irregular expansion of built-up areas in urban areas. Green belts were also expected to help preserve the urban environment, more importantly, military strategic considerations were given and anti-speculation functions were assigned to green belts. Son and Kim (1998) demonstrate empirically that green belts are one of the main causes of urban land shortages. 


\subsection{The Model}

An extensive literature suggests that housing markets do not clear quickly. Peng and Wheaton (1994) used a variation of the traditional stock-flow model by incorporating land supply into the housing market model. Their paper estimates the demand and supply for owner-occupied housing units. This paper modifies the article of Peng and Wheaton (1994) for the Korean housing market.

\subsubsection{Housing Demand}

The demand for owner-occupied housing is a function of real permanent income, $\mathrm{Y}$, the real housing price, HP, the annual user cost of owning housing, UC, the number of households, $\mathrm{HH}$, and the cost of renting, R. With the assumption of perfect financial markets, only the relative annual cost of owning to renting (HP.UC/R) would be needed in the demand equation. In Korea, borrowing constraints have an important effect on housing demand as explained in the previous section. Therefore, this paper specifies separately housing price levels, user costs, and rents into housing demand.

The traditional stock-flow model assumes that housing prices, HP*, adjusts to bring the demand for housing and the existing stock into balance.

$$
\mathrm{D}\left(\mathrm{Y}, \mathrm{HP}{ }^{*}, \mathrm{UC}, \mathrm{R}, \mathrm{HH}\right)=\mathrm{S} .
$$

The term, $\mathrm{UC}$, consists of the interest rate, $i$, the depreciation rate, $\mathrm{d}$, and the expected rate of future housing price appreciation, $\mathrm{EHP}^{3}$.

$$
\mathrm{UC}=(i+\mathrm{d}-\mathrm{EHP}) .
$$

\footnotetext{
${ }^{3}$ Most of literature suggests that the definition of the user cost of homeownership incorporates the after-tax cost of debt and property taxes $\left(i+\mathrm{t}_{\mathrm{p}}\right)\left(1-\mathrm{t}_{\mathrm{y}}\right)$. However, the Korean property tax system has not changed. Therefore, tax rates are excluded.
} 
Expectations of future housing prices appreciation may be modeled in two ways. Adaptive expectations assume that expectations are based on some pattern of current or past market behavior. The problem with using adaptive expectations is that forecasting depends on only error in expectations from the previous period while omitting other useful variables. Alternatively, rational expectation formations uses all relevant current information on the market's operation. According to rational expectations, consumers predict the market response to exogenous changes by adjusting their expectations to the perfect information regarding the market. (Peng and Wheaton 1994). Even though adaptive expectation models are frequently criticized as being ad hoc, many papers suggest that the adaptive expectation formation fits the data better ( Rosen and Smith 1986, Muth 1988, Peng and Wheaton 1994, Choi and Lee 2003).

Peng and Wheaton (1994) specify that the expected rate of future house price appreciation, EHP, is based on two pieces of information. First, consumers predict future price appreciation by looking back to recent rates of price appreciation, $\mathrm{HP}^{e}$, and the quantity of recent new land supply, NLS. This assumption leads to

$$
\mathrm{EHP}=g\left(\mathrm{HP}^{e}-\mathrm{NLS}\right)
$$

The econometric model can be specified by incorporating equations (3.1) through (3.3) and assuming that demand for owner-occupied housing is a linear function of income, house prices, user costs, rents, and the number of households ${ }^{4}$

\footnotetext{
${ }^{4}$ With the assumption of a linear function, substituting equation (3.3) into (3.2) yields two separate parts: $\mathrm{UC}=\left(i+\mathrm{d}-\mathrm{g}\left(\mathrm{HP}^{e}-\mathrm{NLS}\right)=\left(i+\mathrm{d}-\mathrm{HP}^{e}+\mathrm{NLS}\right)=\mathrm{UCO}+\mathrm{NLS}\right.$.
} 


$$
\left(\alpha_{0}+\alpha_{1} \mathrm{HP}_{\mathrm{t}}^{*}+\alpha_{2} \mathrm{Y}_{\mathrm{t}}+\alpha_{3} \mathrm{UCO}_{\mathrm{t}}+\alpha_{4} \mathrm{R}_{\mathrm{t}}+\alpha_{5} \mathrm{HH}_{\mathrm{t}}+\alpha_{6} \mathrm{NLS}_{\mathrm{t}}\right)=\mathrm{S}_{\mathrm{t}}
$$

The expected sign of $\forall_{1}$ is negative because the quantity demanded for housing should decline as the price of housing rises. $\forall_{2}$ is expected to have a positive sign because rising household permanent income raises the demand for housing. The expected sign of $\forall_{3}$ should be negative because the demand for housing units should decrease as the annual opportunity cost of housing rises. Since rental housing is a substitute for owner-occupied housing, the expected sign of $\forall_{4}$ is expected to be positive. The coefficient of the number of households is expected to be positive. Finally, a reduction in land supply causes consumers to expect a shortage of new land for housing construction in the future. If land supply is binding, this expected shortage of land supply will lead to an increase in future rents which in turn will cause higher future housing prices. Expectations of rising future appreciation of housing prices increases the current demand for housing. Therefore, $\forall_{6}$ is expected to be negative.

Solving equation (3.4) for $\mathrm{HP}_{\mathrm{t}}^{*}$ yields

$$
\mathrm{HP}_{\mathrm{t}}^{*}=\frac{1}{\alpha_{1}}\left(\mathrm{~S}_{\mathrm{t}}-\alpha_{0}-\alpha_{2} \mathrm{Y}_{\mathrm{t}}-\alpha_{3} \mathrm{UCO}_{\mathrm{t}}-\alpha_{4} \mathrm{R}_{\mathrm{t}}-\alpha_{5} \mathrm{HH}_{\mathrm{t}}-\alpha_{6} \mathrm{NLS}_{\mathrm{t}}\right)
$$

Even though the traditional stock-flow model assumes that housing prices adjust quickly to equate the demand for housing with the existing stock, there is a convincing evidence that the housing market does not clear instantly (Son 2000, Dipasquale and Wheaton 1994, and Peng and Wheaton 1994)

Dipasquale and Wheaton (1994) provide explanations for gradual price adjustment. Since housing is heterogeneous and requires time-consuming search, 
housing market transactions can take a long time and exhibit significant variance. Therefore, the assumption of slow price adjustment may be rational.

A gradual price adjustment can easily be incorporated into the stock-flow model. Assuming that current housing prices, $\mathrm{HP}_{\mathrm{t}}$, depend on both the unobserved current equilibrium price, $\mathrm{HP}_{\mathrm{t}}^{*}$, and the prices observed in the previous period, $\mathrm{HP}_{\mathrm{t}-1}$.

$$
\mathrm{HP}_{\mathrm{t}}=\gamma \cdot \mathrm{HP}_{\mathrm{t}}^{*}+(1-\gamma) \mathrm{HP}_{\mathrm{t}-1}
$$

where ( represents the percentage rate at which actual prices converge to the market clearing prices. Combining equations (3.5) and (3.6), the complete price specification for empirical estimation is

$$
\begin{aligned}
\mathrm{HP}_{\mathrm{t}} & =\frac{\gamma}{\alpha_{1}}\left(\mathrm{~S}_{\mathrm{t}}-\alpha_{0}-\alpha_{2} \mathrm{Y}_{\mathrm{t}}-\alpha_{3} \mathrm{UCO}_{\mathrm{t}}-\alpha_{4} \mathrm{R}_{\mathrm{t}}-\alpha_{5} \mathrm{HH}_{\mathrm{t}}-\alpha_{6} \mathrm{NLS}_{\mathrm{t}}+(1-\gamma) \mathrm{HP}_{\mathrm{t}-1}\right. \\
& =\beta_{0}+\beta_{1} \mathrm{~S}_{\mathrm{t}}+\beta_{2} \mathrm{Y}_{\mathrm{t}}+\beta_{3} \mathrm{UCO}_{\mathrm{t}}+\beta_{4} \mathrm{R}_{\mathrm{t}}+\beta_{5} \mathrm{HH}_{\mathrm{t}}+\beta_{6} \mathrm{NLS}_{\mathrm{t}}+\beta_{7} \mathrm{HP}_{\mathrm{t}-1}
\end{aligned}
$$

with expectations that $\beta_{2}, \beta_{4}, \beta_{5}, \beta_{7}>0$ and $\beta_{1}, \beta_{3}, \beta_{6},<0$.

\subsubsection{Construction}

The total stock of housing units, S, consists of the depreciated stock of previous housing units and new construction, $\mathrm{CO}$,

$$
\mathrm{S}_{\mathrm{t}}=(1-\delta) \cdot \mathrm{S}_{\mathrm{t}-1}+\mathrm{CO}_{\mathrm{t}}
$$

where $*$ is the depreciation rate.

Construction depends on profit opportunities as reflected in the difference between housing price and the relative costs of construction. In Korea, about 90 percent of total 2002 housing construction was high-rise condominiums which have a long construction period. This implies that current housing completion results from decisions 
made in previous periods. Housing construction is a function of lagged housing prices, lagged cost shifters, and the expected price appreciation on construction.

Many empirical papers suggest that land prices are also a major determinant of housing construction. However, only the government develops land for housing construction at the fringe of city. In addition, high-rise condominium complex is built in the developed area, which means that construction companies can substitute capital for land to respond to higher land prices. Therefore, this essay does not include land prices as a major determinant of housing construction. While land prices are not considered as a factor of construction, restrictive land-use regulations requires the quantity of new land supplied to be incorporated into the construction equation. Peng and Wheaton (1994) take this approach of using new land supplied rather than land prices.

In Korea, as the cities rapidly grow, land development for housing construction is in complete controlled by the government. Therefore, it could be important to analyze how the government plays a role in bringing the housing stock into equilibrium through new construction. Since the government-supported company, KHNC, has been directly involved in housing construction, construction made by $\mathrm{KHNC}$ is subtracted from the total housing construction to measure private construction in this essay. Dipasquale and Wheaton (1994) introduce a housing construction model by combining a stock adjustment process with a definition of the long run equilibrium housing stock

$$
\mathrm{CO}=\tau \cdot\left(\mathrm{S}^{*}(\mathrm{HP}, \mathrm{X})-\mathrm{S}\right)
$$

where $\mathrm{S}^{*}$ is the long run stock of housing, HP is housing prices, $\mathrm{X}$ is cost shifters, $\mathrm{S}$ is the current stock levels, and $\vartheta$ represents the speed with which the stock adjusts through new construction. This implies that housing price levels results in new construction only 
temporary until the current housing stock catches up to the long-run stock, $\mathrm{S}^{*}$, determined by rent theory. The long-run stock rapidly grows and leads the current stock in a growing city. As a result, many housing units are constructed in a growing city. However, in a large city the current stock already adjusts to the equilibrium with high housing prices. Therefore, a large city experiences little or no construction. In addition to the government's direct involvement in housing construction, the cities in Korea have grown dramatically. Under these circumstances, it could be meaningful to analyze how fast the stock adjusts to the long run equilibrium under the land-use regulation. If the long run stock is a linear function of housing prices, and cost shifters, it is

$$
\mathrm{S}^{*}=\mathrm{a}_{0}+\mathrm{a}_{1} \mathrm{HP}+\mathrm{a}_{2} \mathrm{X}
$$

Substituting Equation (3.10) into Equation (3.9) yields construction function as house prices, HP, cost shifters, and the actual stock of housing, S. In addition, construction depends on land-use regulations. New land supply, NLS, is incorporated into construction equation to see whether land-use regulations have a binding effect on construction. Finally, construction is also affected by the general economy. Under the assumption of a linear form, the estimating construction equation can be written as follows:

$$
\begin{aligned}
\mathrm{C}_{\mathrm{t}} & =\tau\left(\mathrm{S}^{*}-\mathrm{S}\right) \\
& =\tau\left(a_{0}+a_{1} \mathrm{HP}_{\mathrm{t}-1}+a_{2} \Delta \mathrm{HP}_{\mathrm{t}}+a_{3} i_{\mathrm{t}-1}+a_{4} \mathrm{CC}_{\mathrm{t}-1}+a_{5} \text { Wage }_{\mathrm{t}-1}\right. \\
& \left.+a_{6} \mathrm{Unemp}_{\mathrm{t}-1}+a_{7} \text { Dummy } a_{8} \mathrm{NLS}_{\mathrm{t}-1}\right)-\tau \mathrm{S}_{\mathrm{t}-1} \\
& =\lambda_{0}+\lambda_{1} \mathrm{HP}_{\mathrm{t}-1}+\lambda_{2} \Delta \mathrm{HP}_{\mathrm{t}}+\lambda_{3} i_{\mathrm{t}-1}+\lambda_{4} \mathrm{CC}_{\mathrm{t}-1}+\lambda_{5} \mathrm{Wage}_{\mathrm{t}-1} \\
& +\lambda_{6} \mathrm{Unemp}_{\mathrm{t}-1}+\lambda_{7} \text { Dummy }+\lambda_{8} \mathrm{NLS}_{\mathrm{t}-1}-\tau \mathrm{S}_{\mathrm{t}-1},
\end{aligned}
$$


where $\lambda_{0}=\tau \cdot a_{0}, \lambda_{1}=\tau \cdot a_{1}, \lambda_{2}=\tau \cdot a_{2}, \lambda_{3}=\tau \cdot a_{3}, \lambda_{4}=\tau \cdot a_{4}, \lambda_{5}=\tau \cdot a_{5}, \lambda_{6}=\tau \cdot a_{6}$, $\lambda_{7}=\tau \cdot a_{7}$, and $\lambda_{8}=\tau \cdot a_{8} . \Delta \mathrm{HP}$ is the change in real housing price $\left(\mathrm{HP}_{\mathrm{t}}-\mathrm{HP}_{\mathrm{t}-1}\right)$ and reflects change perceived by speculative builders (Peng and Wheaton 1994) ${ }^{5}, \mathrm{CC}$ is construction raw material price index ${ }^{6}$, Wage is construction wage rate, $i$ is the real interest rate of housing construction financing, Unemp is unemployment rate and represents the general economic condition, Dummy variable represents the economic crisis in 1998, and $\vartheta$ is interpreted as the annual rate with which the stock adjust to its long run desired level through construction.

The expected signs of $8_{1}$ and $8_{2}$ are positive since the profitability of housing construction rises as housing prices increase or price appreciation rise. Conversely, the profitability of housing construction declines as interest rates, construction costs, or wage increase. Hence, $8_{3}, 8_{4}$, and $8_{5}$ are expected to have a negative signs. A positive sign of $8_{6}$ is expected since construction tends to have a negative correlation with unemployment rate. Since economic activities in all sectors plummeted in 1998 due to the economic crises, the sign of $8_{7}$ is anticipated to be negative. Finally, if land-use regulation has a binding effect on construction, it is claimed that land supply does not exert a positive impact on construction. Therefore, the expected sign of $8_{8}$ should not be positive.

\subsection{Data and Variable Definitions}

\footnotetext{
${ }^{5}$ Like Peng and Wheaton (1994), it is found that the empirical model using current price change provides better results rather than previous price change $\left(\mathrm{HP}_{\mathrm{t}-1}-\mathrm{HP}_{\mathrm{t}-2}\right)$.

${ }^{6}$ In most literature, labor and material construction costs are computed as a single construction cost index, however, a single construction cost index is not available in Korea during the data period. Therefore, construction material price index and wage are separately incorporated.
} 
While an aggregate housing model should take account of the demand and supply for total housing services, most stock-flow models have been specified in terms of housing units. Since the government provides the data for the number of units, this paper models the market for housing units.

Kookmin Bank (KB) has produced the quality-adjusted housing price index. Kim (1993) demonstrates the ways of measuring housing prices in the Korean housing market. The housing price index has three different measures. The index from 1974 to 1977 is a weighted average of the total factor cost (including land) of constructing 13 pyong $^{7}$ apartments and 43 pyong single-family detached units; the index from 1978 to 1981 is based on the KHB standard construction cost (exclusive of land cost); and the index from 1982 to 2002 is taken from information on actual transacted or estimated prices provided to KHB by real estate agents. Therefore, data for prices prior to 1982 are likely to understate the value at that time.

The current paper uses only the stock of owner-occupied housing. The Ministry of Construction and Transportation (MOCT) provides the data for stock series. Since the data include owner-occupied and rental housing units, rental units should be subtracted from the MOCT's data series in order to obtain only owner-occupied housing stock. Data for the rental stock series are obtained from various issues of Year Book of Housing Statistics published by Korea National Housing Corporation.

Data for households are available by National Statistical Office (NSO) every five years. Therefore, the total number of households is derived from the supply ratio $(\mathrm{S} / \mathrm{HH})$ provided by MOCT. The problem associated with this estimation is that the denominator

\footnotetext{
${ }^{7}$ One pyong is equal to 3.3 square meters.
} 
excludes one-person households and non-blood related households. Therefore, it underestimates the number of households at the national level.

According to the Permanent Consumption theory, personal consumption data are used as a proxy for permanent income. The rent data used in this paper are the NSO chonsei index which is a component of the consumer price index.

The estimation of the user cost of homeownership is based on various sources. First, data for mortgage interest rate take National Housing Fund's interest rates on Loans from several issues of Year Book of Housing Statistics published by the Korea National Housing Corporation(KNHC). Second, the depreciation rate uses the depreciation rate of real estate and rental industry provided by NSO.

Land supply data are permitted land supply for dwellings provided by MOCT. These data is measured as the total square meters of land permitted for dwellings during the calendar year.

Since a single construction cost index for labor and material through the whole analysis period, this paper separately uses two cost variables as a proxy of construction cost index: Producer Price Index of construction raw materials and wage.

The real interest rates of construction financing are National Housing Fund's interest rates on Housing Construction Loans from several issues of Year Book of Housing Statistics published by the KNHC.

Housing price, construction costs, interest rates, and income, are all inflationadjusted terms using the Consumer Price Index.

\subsection{Empirical Results}




\subsubsection{Housing Price Estimation}

Since most variables in the housing price equation have a time trend, the differences equation is estimated. Housing price equation is estimated with a set of time variations for new land supply to test how long new land supply takes to affect housing prices through expectation adjustments of consumers. Furthermore, since current rents and current land supply are likely to be endogenous, all housing price equations are estimated by two-stage least squares.

$$
\begin{aligned}
\Delta \mathrm{HP}_{\mathrm{t}}= & \beta_{1} \Delta \mathrm{S}_{\mathrm{t}}+\beta_{2} \Delta \mathrm{Y}_{\mathrm{t}}+\beta_{3} \Delta \mathrm{UCO}_{\mathrm{t}}+\beta_{4} \Delta \mathrm{R}_{\mathrm{t}}+\beta_{5} \Delta \mathrm{HH}_{\mathrm{t}} \\
& +\beta_{6} \Delta \mathrm{LS}+\beta_{7} \Delta \mathrm{HP}_{\mathrm{t}-1}
\end{aligned}
$$

Table 3.2 presents the results of housing price estimation ${ }^{8}$. The Breusch-Godfrey Lagrange Multiplier statistics suggest that error terms are not serially correlated. The first case omits both the land supply and the lagged prices, while the second case omits only the land supply. The lagged housing prices are significant and the value of $R^{2}$ jumps and the magnitude of coefficients significantly change with the addition of the lagged price. The result supports the hypothesis of a gradual price adjustment. The estimated value of $\vartheta$ from the case 5 is 0.3 , which means that price slowly adjusts to long run equilibrium price.

Cases 3 to 6 in table 2 incorporate the effect of new land supply into housing prices equation. All of the coefficients of land supplies in cases 3 to 6 have the negative signs as expected. The result suggests that the Korean housing market is land restrictive.

\footnotetext{
${ }^{8}$ The regression model is estimated by including the two dummy variables: one dummy variable represents the Two Million Housing Construction from 1988 to 1992 and the other represents the financial crisis in 1998. However, the results show that the coefficients of those two dummy variables are never significant. Therefore, the regression model does not include the dummy variables.
} 
The coefficients of current land supply (case 3) and three-year lagged land supply are not statistically significant. But cases 4 to 5 present the statistically significant coefficients of the one-year or two-year lagged land supplies. The result suggests that the expectation adjustment with respect of land supply take place only after the exogenous shock. Furthermore, case 5 shows that all the variables are significant except rent and the highest

\section{Table 3.2 Housing Price Equation}

Dependent Variable: change in Housing Prices

\begin{tabular}{|c|c|c|c|c|c|c|}
\hline $\begin{array}{l}\text { Independent } \\
\text { Variable }\end{array}$ & Case 1 & Case 2 & Case 3 & Case 4 & Case 5 & Case 6 \\
\hline $\begin{array}{l}\text { Change in } \\
\text { Housing Stock }\end{array}$ & $\begin{array}{c}-0.000048^{* *} \\
(-2.56)\end{array}$ & $\begin{array}{c}-0.000022 * * \\
(-2.58)\end{array}$ & $\begin{array}{c}-0.000015 \\
(-1.64)\end{array}$ & $\begin{array}{c}-0.000022^{*} \\
(-1.85)\end{array}$ & $\begin{array}{c}-0.000023^{* *} \\
(-2.72)\end{array}$ & $\begin{array}{c}-0.000021^{* *} \\
(-2.55)\end{array}$ \\
\hline $\begin{array}{l}\text { Change in } \\
\text { Income }_{t}\end{array}$ & $\begin{array}{l}0.00066^{* *} \\
(2.34)\end{array}$ & $\begin{array}{c}0.00037 * * * \\
(3.09)\end{array}$ & $\begin{array}{c}0.00014 \\
(0.55)\end{array}$ & $\begin{array}{l}0.00037 * * \\
(2.57)\end{array}$ & $\begin{array}{c}0.00031 * * * \\
\quad(3.08)\end{array}$ & $\begin{array}{c}0.00037 * * * \\
\quad(3.17)\end{array}$ \\
\hline $\begin{array}{l}\text { Change in } \\
\text { Rent } t_{t}(I V)\end{array}$ & $\begin{array}{l}-2.74 \\
(-0.4)\end{array}$ & $\begin{array}{l}-2.52 \\
(-0.78)\end{array}$ & $\begin{array}{l}-2.76 \\
(-0.92)\end{array}$ & $\begin{array}{l}-2.02 \\
(-0.60)\end{array}$ & $\begin{array}{l}-2.18 \\
(-0.64)\end{array}$ & $\begin{array}{l}-2.32 \\
(-0.64)\end{array}$ \\
\hline $\begin{array}{l}\text { Change in User } \\
\text { Cost }_{t}\end{array}$ & $\begin{array}{c}-0.83 * * * \\
(-3.62)\end{array}$ & $\begin{array}{c}-1.40 * * * \\
(-7.90)\end{array}$ & $\begin{array}{c}-1.29 * * * \\
(-8.97)\end{array}$ & $\begin{array}{c}-1.38 * * * \\
(-7.18)\end{array}$ & $\begin{array}{c}-1.40 * * * \\
(-9.59)\end{array}$ & $\begin{array}{c}-1.37 * * * \\
(-7.36)\end{array}$ \\
\hline $\begin{array}{l}\text { Change in } \\
\text { Households }_{t}\end{array}$ & $\begin{array}{c}0.038^{* *} \\
(2.40)\end{array}$ & $\begin{array}{l}0.02 * \\
(1.74)\end{array}$ & $\begin{array}{l}0.015 \\
(1.67)\end{array}$ & $\begin{array}{l}0.018 \\
(1.30)\end{array}$ & $\begin{array}{l}0.024 * \\
(2.06)\end{array}$ & $\begin{array}{l}0.016 \\
(1.53)\end{array}$ \\
\hline $\begin{array}{l}\text { Change in } \\
\text { Housing Price }{ }_{t-1}\end{array}$ & & $\begin{array}{c}0.73 * * * \\
(6.28)\end{array}$ & $\begin{array}{c}0.70 * * * \\
(6.99)\end{array}$ & $\begin{array}{c}0.70 * * * \\
(3.52)\end{array}$ & $\begin{array}{c}0.70 * * * \\
(5.53)\end{array}$ & $\begin{array}{c}0.69 * * * \\
(5.58)\end{array}$ \\
\hline $\begin{array}{l}\text { Change in New } \\
\text { Land Supply }(\mathrm{IV})\end{array}$ & & & $\begin{array}{c}-0.00032 \\
(-1.33)\end{array}$ & & & \\
\hline $\begin{array}{l}\text { Change in New } \\
\text { Land Supply }\end{array}$ & & & & $\begin{array}{l}-0.0001 \\
(-0.08)\end{array}$ & & \\
\hline $\begin{array}{l}\text { Change in New } \\
\text { Land Supply } \mathrm{t}_{\mathrm{t}-2}\end{array}$ & & & & & $\begin{array}{l}-0.00033 \\
(-2.30)^{* *}\end{array}$ & \\
\hline $\begin{array}{l}\text { Change in New } \\
\text { Land Supply }{ }_{\mathrm{t}-3}\end{array}$ & & & & & & $\begin{array}{c}-0.00009 \\
(-0.86)\end{array}$ \\
\hline $\mathrm{R}^{2}$ & 0.51 & 0.84 & 0.85 & 0.84 & 0.89 & 0.85 \\
\hline LM & 0.86 & 0.63 & 1.37 & 0.68 & 1.22 & 0.30 \\
\hline
\end{tabular}




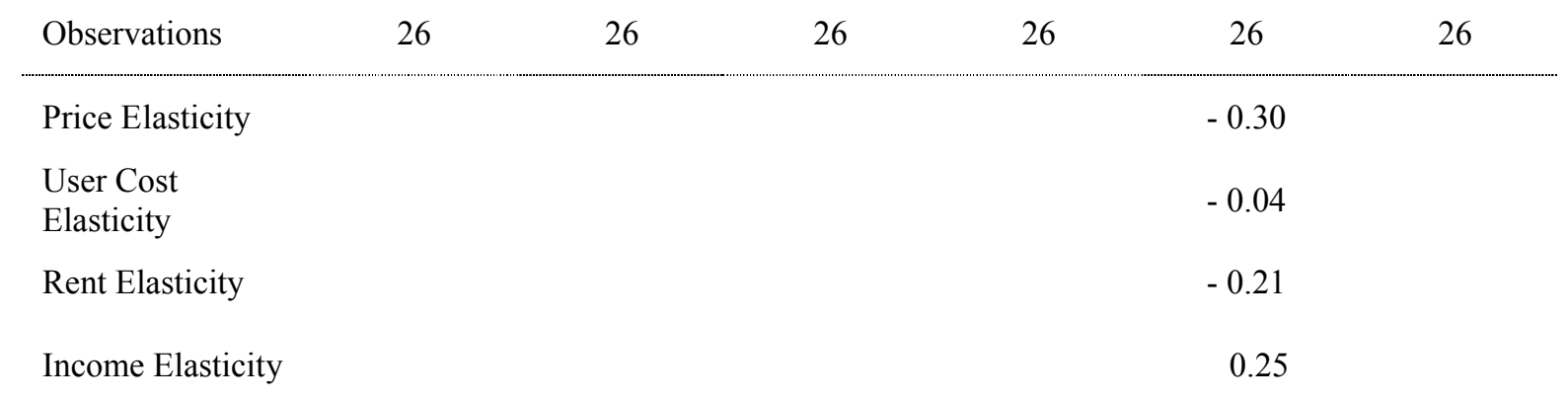

Note: The parenthesis is t value; ${ }^{* * *}, \mathrm{p}<0.01 ;{ }^{* *}, \mathrm{p}<0.05 ;{ }^{*}, \mathrm{p}<0.1$

The instruments for rent, R(IV), are lagged endogenous and current exogenous variables. For current new land supply, the instruments are population and current exogenous variables. 
$\mathrm{R}^{2}$. It is interpreted that the effects of land supply on housing prices take two years to reach the market. The insignificances of current and three-year land supplies suggest that consumers can't adjust immediately their expectations or the effects of land supply on housing prices do not exist too long.

The results in table 3.2 show that the stock of housing has a significant negative effect on housing prices. Income has a significant positive effect. While rents have the unexpected sign it is never significant. The user cost of capital exerts a negative effect on housing prices. The number of households has a significant positive effect on housing prices.

Table 3.2 presents calculated elasticities ${ }^{9}$ of housing demand with respect to permanent income, housing prices, user costs, and rents. The income elasticity of housing demand is 0.25 . The price elasticity of housing demand is -0.3 .

Dipasquale and Wheaton (1994) show that the importance of comparison among the demand elasticities with respect to price, user cost and rent. The price elasticity of demand should be equal to the demand elasticities with respect to user cost and rent in a perfect financial market but not in a constrained market. Since this paper assumes that the Korean housing financial market is not perfect, it is useful to compare the price elasticity of demand with the demand elasticities with respect to user cost and rent. While the user cost elasticity of demand shows -0.033 which is very different from the price elasticity of demand, the rent elasticity of demand is -0.21 , closer to the price elasticity. However, rent is insignificant. The comparison of the elasticities supports that housing market has

\footnotetext{
${ }^{9}$ From equations (3) to (7), the price elasticity is $\left(1-\beta_{7}\right) \cdot \mathrm{HP} / \beta_{1} \cdot \mathrm{S}$. The income elasticity of demand is $\beta_{2} \cdot \mathrm{Y} / \beta_{1} \cdot \mathrm{S}$. The user cost elasticity is $-\beta_{3} \cdot \mathrm{UCO} / \beta_{1} \cdot \mathrm{S}$. The rent elasticity is $-\beta_{4} \cdot \mathrm{R} / \beta_{1} \cdot \mathrm{S}$. The estimated coefficients from equation (12) can be used for elasticity calculation. HP, S, Y, UCO, and R are the values of the sample mean.
} 
the constraints of financial market and furthermore housing prices are more important than rents, interest rates, and expectation about housing price appreciation in determining demand for owner-occupied housing.

\subsubsection{Housing Construction Estimation}

Private construction is used for housing construction estimation. Housing construction equation is also estimated with a set of time variations for new land supply to test how long the effects of new land supply on construction takes to reach the market. Table 3.3 shows estimated results of housing completion. As in the case of housing price equation, the Breusch-Godfrey Lagrange Multiplier statistics suggest that error terms are not serially correlated.

Case 1 excludes both land supply and lagged housing stock variables. Only two variables are significant: change in housing prices and wage. Incorporating the lagged housing stock variable raises R-square and improve the significance. Even though wage has a significant positive sign in case 1 , it is not statistically significant other cases. Furthermore, the sign of construction material cost variable is negative (except case 1) but insignificant. Both housing prices and price change have their expected signs and are statistically significant. The coefficient of real interest is significant negative as expected. The coefficient of unemployment variable has an expected sign. However, it is rarely significant. This result suggests that housing construction does not depend on the general economic conditions. As Kim (2003) indicates, it might be explained by the fact that the Korean government has used residential investment to counter business fluctuations. The 
Table 3.3 Construction Equation

\begin{tabular}{|c|c|c|c|c|c|c|}
\hline \multicolumn{7}{|c|}{ Dependent Variable: Housing Construction } \\
\hline $\begin{array}{l}\text { Independent } \\
\text { Variable }\end{array}$ & Case 1 & Case 2 & Case 3 & Case 4 & Case 5 & Case 6 \\
\hline Constant & $\begin{array}{l}-425486 \\
(-1.71)\end{array}$ & $\begin{array}{l}-444761^{* *} \\
(-2.31)\end{array}$ & $\begin{array}{c}-374708^{*} \\
(-1.78)\end{array}$ & $\begin{array}{l}-583551^{* *} \\
(-2.68)\end{array}$ & $\begin{array}{l}-627648^{* *} \\
(-2.70)\end{array}$ & $\begin{array}{l}-801289 * * * \\
\quad(-4.36)\end{array}$ \\
\hline Housing Price $_{t-1}$ & $\begin{array}{c}1387.69 \\
(1.61)\end{array}$ & $\begin{array}{l}2020.47 * * * \\
(2.93)\end{array}$ & $\begin{array}{l}1702.37^{* *} \\
(2.15)\end{array}$ & $\begin{array}{l}2007.24 * * \\
(2.80)\end{array}$ & $\begin{array}{l}2228.63^{* *} \\
(2.61)\end{array}$ & $\begin{array}{l}3148.18^{* * *} \\
\quad(4.06)\end{array}$ \\
\hline $\begin{array}{l}\text { Change in Housing } \\
\text { Price }_{t}\end{array}$ & $\begin{array}{l}3899.49^{* *} \\
(2.64)\end{array}$ & $\begin{array}{l}3065.51^{* *} \\
\quad(2.63)\end{array}$ & $\begin{array}{l}3112.44^{* *} \\
\quad(2.65)\end{array}$ & $\begin{array}{l}2642.71 * * \\
(2.17)\end{array}$ & $\begin{array}{l}3111.35^{* *} \\
\quad(2.56)\end{array}$ & $\begin{array}{l}3143.36^{* * *} \\
\quad(3.33)\end{array}$ \\
\hline Interest rate $_{\mathrm{t}-1}$ & $\begin{array}{c}1541.80 \\
(0.50)\end{array}$ & $\begin{array}{l}-7531.09^{* *} \\
(-2.21)\end{array}$ & $\begin{array}{c}-7282.25^{*} \\
(-2.11)\end{array}$ & $\begin{array}{c}-7004.05^{*} \\
(-1.83)\end{array}$ & $\begin{array}{l}-4790.20 \\
(-1.10)\end{array}$ & $\begin{array}{c}-5907.57 \\
(-1.76)\end{array}$ \\
\hline $\begin{array}{l}\text { Construction } \\
\text { material Cost } t_{t-1}\end{array}$ & $\begin{array}{r}306.13 \\
(0.39)\end{array}$ & $\begin{array}{l}-55.42 \\
(-0.09)\end{array}$ & $\begin{array}{l}-93.74 \\
(-0.15)\end{array}$ & $\begin{array}{l}-385.34 \\
(-0.55)\end{array}$ & $\begin{array}{c}-158.96 \\
(-0.21)\end{array}$ & $\begin{array}{l}-194.86 \\
(-0.37)\end{array}$ \\
\hline Wage $_{t-1}$ & $\begin{array}{l}962.62 * * * \\
(4.38)\end{array}$ & $\begin{array}{r}229.75 \\
(0.88)\end{array}$ & $\begin{array}{l}111.77 \\
(0.37)\end{array}$ & $\begin{array}{r}426.57 \\
(1.41)\end{array}$ & $\begin{array}{r}445.82 \\
(1.36)\end{array}$ & $\begin{array}{r}334.09 \\
(1.40)\end{array}$ \\
\hline $\begin{array}{l}\text { Unemployment } \\
\text { Rate }_{t-1}\end{array}$ & $\begin{array}{c}-4569.83 \\
(-0.31)\end{array}$ & $\begin{array}{l}-30089.9^{* *} \\
(-2.21)\end{array}$ & $\begin{array}{c}-24733.04 \\
(-1.64)\end{array}$ & $\begin{array}{c}-31741.4^{* *} \\
(-2.24)\end{array}$ & $\begin{array}{l}-21657.00 \\
(-1.41)\end{array}$ & $\begin{array}{l}-19100.30 \\
(-1.65)\end{array}$ \\
\hline Dummy & $\begin{array}{l}-155683.8 \\
(-1.60)\end{array}$ & $\begin{array}{l}-204871 * * \\
(-2.68)\end{array}$ & $\begin{array}{l}-204164 * * \\
(-2.65)\end{array}$ & $\begin{array}{l}-208214^{* *} \\
(-2.72)\end{array}$ & $\begin{array}{c}-190990^{* *} \\
(-2.43)\end{array}$ & $\begin{array}{c}-190770^{* * *} \\
(-3.14)\end{array}$ \\
\hline Housing Stock $\mathrm{t}_{\mathrm{t}-1}$ & & $\begin{array}{l}-0.06^{* * * *} \\
(3.70)\end{array}$ & $\begin{array}{c}-0.05 * * * \\
(3.00)\end{array}$ & $\begin{array}{c}-0.06^{* * * *} \\
(-3.85)\end{array}$ & $\begin{array}{c}-0.06^{* * *} \\
(3.61)\end{array}$ & $\begin{array}{c}-0.07 * * * \\
(5.59)\end{array}$ \\
\hline New Land Supply $\mathrm{y}_{\mathrm{t}-1}$ & & & $\begin{array}{c}1.71 \\
(0.84)\end{array}$ & & & \\
\hline New Land Supply $\mathrm{t}_{-2}$ & & & & $\begin{array}{l}-2.75 \\
(-1.42)\end{array}$ & & \\
\hline New Land Supply $\mathrm{t}_{\mathrm{t}-3}$ & & & & & $\begin{array}{l}-1.56 \\
(-0.87)\end{array}$ & \\
\hline New Land Supply $y_{t-4}$ & & & & & & $\begin{array}{l}-1.15 \\
(-1.00)\end{array}$ \\
\hline $\mathrm{R}^{2}$ & 0.81 & 0.89 & 0.90 & 0.90 & 0.90 & 0.94 \\
\hline LM & 0.80 & 0.59 & 0.55 & 0.64 & 0.59 & 0.33 \\
\hline Observations & 26 & 26 & 26 & 26 & 26 & 26 \\
\hline $\begin{array}{l}\text { Price elasticity of } \\
\text { Construction }\end{array}$ & & & & & & 1.10 \\
\hline $\begin{array}{l}\text { Price Elasticity } \\
\text { of Stock }\end{array}$ & & & & & & 1.08 \\
\hline
\end{tabular}


anticipated significant sign of Dummy variable implies that construction was affected by the economic crisis in the late 1990s.

Land supply has a positive sign in case 1 but negative sign in other cases. However, land supply variable is never significant. These results suggest that land supply has no effect on housing construction. Therefore, it is claimed that land-use regulation has constrained housing construction. The results provide evidence that increase in housing prices result from a shortage of housing units which have been construed by land-use regulations.

The stock coefficient in this model represents the speed with which the stock adjusts through new construction. The magnitude of the coefficient ranges from 0.05 to 0.07 which implies a very slow stock adjustment process. This results from the fact that new construction, in general, is a small portion of the total stock. The ratio of construction in the total stock has ranged from 1.76 to 7.87 per cent over the sample period. However, it seems likely that the speed of stock adjustment through new construction in the Korean housing market is a lot faster than in the general case. Dipasquale and Wheaton (1994) presents 2 percent for the stock adjustment speed through new construction in American housing market. The faster stock adjustment in the Korean housing market could be explained by the involvement of the government in large housing construction projects and redevelopment.

Since R squared measures favor case 6 by providing the highest value, case 6 is used to calculate the price elasticity of construction: 1.10 and the long run elasticity of the stock ranges from $1.08^{10}$. This is to be expected given the fact that the price elasticity of

\footnotetext{
${ }^{10}$ The price elasticity of construction is $8_{1} \cdot \mathrm{HP}_{\mathrm{t}} / \mathrm{CO}_{\mathrm{t}}$. The elasticity of the desired stock with respect to price is $8_{1} \cdot \mathrm{HP}_{\mathrm{t}} / \vartheta \cdot \mathrm{S}_{\mathrm{t}}$. CO is the value of the sample mean.
} 
the desired stock must be equal to that of construction in a long run steady state. This result is in contrast with early literature which claims that the government policies were aimed at controlling prices and suppressing speculation rather than providing more land supply and housing construction. Under the land-use regulation for housing construction, therefore, the price elasticity of the stock is inelastic. However, the government has implemented large scale land development from the late 1980s in order to stabilize housing prices. The land supply from 1988 to 2002 is approximately 78 percent of total land supply over the sample period. Furthermore, since the ratio of floor space in a building to the site area covered by that building is large, the huge high-rising condominium complex has been built in developed large scale land. The high-rising condominium units have been around $90 \%$ of total housing construction since the early 1990s. Those recent government policies on land supply and housing construction seems to contribute to elastic housing supply.

\subsection{Conclusion}

Even though many articles have claimed that the Korean housing market has been land restrictive, there is no empirical paper that has analyzed how land-use regulations affect the Korean housing market. This paper performs the empirical analysis of the effects of land-use regulations on the Korean housing market using an econometric approach. If a shortage of land supply is expected, the housing market stimulates higher investment demand for housing which in turn increases current housing prices. Furthermore, land-use regulations have restrictive effects on housing construction. 
Therefore, land-use regulations result in not only the shortage of housing production but also higher housing prices by increasing investment demand for housing.

The current paper presents evidence of a slow price adjustment process in the Korean housing market. The estimated demand specification of the housing market provides income, price, user cost and Chonsei rent elasticities for housing unit demand. The comparison of price elasticities with user cost and Chonsei rent provides evidence of constrained financial market. The model in this paper suggests that housing prices play a greater role in determining homeownership demand than user cost and Chonsei rent. Muth's stock adjustment model fits housing construction in the Korean housing market. Even though early literature claims that housing supply in Korean housing market is inelastic with housing prices, the model in this paper shows that the price of housing supply is elastic. The results imply that the government recently has played a role in responding to housing markets by developing land supply and being involved in housing construction. 


\section{Chapter 4 \\ The Impact of New Urbanist Redevelopment on Housing Prices}

\subsection{Introduction}

Regional disparities are a common problem of planners, policymakers, and local residents. However, Seoul, the capital of South Korea, has had regional disparities in terms of housing, local economy, educational environment, and finance among the intracity districts, especially between the northern less developed and southern newly developed areas of the River Han since the 1980s. Many indicators of housing market reveal differences between the northern less developed and southern newly developed areas. The northern area district experienced the highest rate of dilapidated houses, 23.4 percent while most districts in the southern areas have the lower rate than the city average, 4.5 percent. The Southern districts also have the highest ratio of housing stocks to households and housing area per person.

The Seoul government has placed its top priority on resolving the regional disparities by revitalizing less developed areas. In October, 2002 and November, 2003, the Seoul government announced the New Town redevelopment which revitalizes 15 less developed areas as one of the antidotes to the regional disparities. While there are many approaches to improve neighborhoods, the New Town project is based on mixed land uses for open space, commercial, and residential housing. Some of the areas are developed by mixing residential housing with public parks while others contain residential housing and commercial uses. Mixed land uses has evoked considerable academic discussion. Advocates of new urbanism believe that mixed land uses is the remedy for a set of problems such as considerable commute times, traffic congestion, air 
pollution, loss of open space, and job housing imbalance caused by zoning regulations. Critics claim that households do not care about the features of new urbanism. However, there is little literature to address the questions on whether different types of mixed land uses generate significantly different spillovers and how the mixture of land uses is valued. Tu and Eppli (1999) found that the values of housing are higher in a new urbanist neighborhood than those in a suburban neighborhood. Song and Knaap $(2003,2004)$ develop quantitative measures of mixed land uses and analyze the impact of mixed land use on housing prices in its vicinity. They show that the impact on housing prices depend on the characteristics of mixed land uses.

The purposes of this paper are to analyze three issues. First, all of the literature typically employs a simple hedonic housing price analysis to examine the effects of neighborhood revitalization on housing prices. However, it is widely believed that housing prices are likely to exhibit spatial dependence. Therefore, inappropriate treatment of spatial dependence leads to the problems for estimation and inference problems. To cope with the problem of spatial dependence, this paper is to investigate whether the spatial hedonic price model is valid for an analysis of neighborhood spillovers on housing prices in the Korean housing market. Secondly, it is very possible that different types of revitalization with different mixed land uses might generate different impacts on their surrounding housing prices. This paper attempts to analyze whether neighborhood spillovers of revitalization on housing prices depend on a type of revitalization with different mixed land uses: open space and commercial uses. Third, there has been little research on whether the announcement of revitalization neighborhoods has an effect on housing prices. This paper is to examine whether and how housing markets respond to 
the announcement of the New Town redevelopment project. A pre-post design of the announcement of the New Town Project is employed to capture the anticipation of the future effects of the completed project.

Before proceeding, the following section of this paper contains a brief review of the literature on mixed land use development and revitalization neighborhood. Section 3 presents an overview on the New Town Project. Section 4 describes the data. Section 5 presents a brief description of the spatial hedonic pricing model. Section 6 presents our empirical results. Concluding remarks are offered in the last section.

\subsection{Literature Review}

While there are many ways to perform neighborhood revitalization strategies, new urbanism suggests that neighborhood development programs require mixing residential and nonresidential uses. Mixed land uses is one of the principles of smart growth which has been widely advocated against urban sprawl. Urban sprawl is characterized by low density, unplanned, automobile dependent, homogeneous, and aesthetically unpleasant. Urban sprawl has been criticized as a cause of a low quality of life because it results in adverse effects on environmental quality, social cohesion, government finance, and human health. Proponents of mixed land uses argue that a mixture of residential, commercial, and employment uses can mitigate socioeconomic problems caused by unplanned development.

The preservation and development of open space are central issue in the ongoing debate about urban sprawl. Several papers analyzed the effects of open space on housing prices. Irwin (2002) Irwin and Bockstael (2001) found a premium associated with 
permanently preserved open space relative to developable one. They tested whether open space exerts spillovers on residential property values by disaggregating open space such as preserved vs. developable. They used a simple instrument variable technique to address the identification problems which arise in a hedonic pricing model. Their empirical results indicate that identification strategies such as the instrument variables approach are necessary to test the effects of land use externalities on property values.

There are a couple of studies that examined the effects of the pattern of surrounding land uses on the value of residential land. Acharya and Bennett (2001) and Geoghegan et al (1997) calculated measures of open space, land-use diversity. They incorporated data into a hedonic pricing model in order to test whether variations in neighborhood variables and land-use pattern have an effect on housing prices. Their empirical results show that the effects of land-use diversity and fragmentation on housing prices depend on whether housing is in a highly developed area, a suburban area, or a relatively rural area. Overall, people prefer to live in places with more homogeneous land use in the immediate neighborhood while diversity and fragmentation of land uses have a positive effect on housing prices in the highly developed areas because of some positive amenities such as walkable access to shopping areas, public transit, or schools. Their findings indicated that housing values are determined by structural characteristics, neighborhood socioeconomic variables, and development level of land use. However, they did not examine the effects of each type of mixed land use on housing prices

Cao and Cory (1981) explored whether property values tend to be higher in the proximity to non-residential land uses such as industrial, commercial, multi-family and public land uses by using the data from Tuscon, AZ. They showed that increasing 
industrial, commercial, multi-family and public land uses tend to increase surrounding home values. They developed a theoretical model of consumer behavior and showed that the effect of non-residential activity on property value depends on the relative strength of the positive and negative external effects generated. Their empirical finding showed that increase in amounts of economic activity result in higher surrounding property values. $\mathrm{Li}$ and Brown (1980) examined the impacts of proximity to non-residential land uses on housing prices by incorporating three types of micro-neighborhood variables for accessibility and external diseconomies. They used noise pollution and the on-site visual quality index for external diseconomies. They provided evidence that housing prices rose due to accessibility, but fell due to problems such as unsightliness and noise pollution. They showed also that including three types of micro-neighborhood variables significantly offset the effect of some aggregate neighborhood variables such as median income.

Bohl (2000) described the growing demand for mixed land uses to revitalize distressed inner-city neighborhoods. He claimed that mixing land uses can strengthen communities by creating more pedestrian-friendly environments, facilitating more interpersonal interaction, and increasing property values. In assessing applications and implications of new urbanism, he suggests that new urbanist design principles need to be viewed as an overall strategy for revitalizing inner-city neighborhoods. Tu and Eppli (1999) tested whether new urbanist neighborhoods exhibit price premiums over traditional suburban neighborhoods, using data from Kentlands, Maryland that is eon of the best examples of new urbanist developments. Their empirical results indicated that 
single-family homeowners are willing to pay to live in a community with new urbanist features.

However, none of the literature above disaggregated mixed land use to examine how different types of mixed land uses affect housing prices. Song and Knaap (2003, 2004) are only studies that examine how different types of mixed land uses are valued. They develop quantitative measure of mixed land uses with the Geographic Information System (GIS) data and incorporate these measures into a hedonic pricing model. Their findings show that housing prices increase with their proximity to public parks or commercial land uses. However, they found that housing prices are lower in neighborhoods dominated by multi-family residential units.

Even though Irwin (2002), Irwin and Bockstael (2001), Song and Knaap (2003, 2004) addressed the endogenous problems between housing price and land use, none of the literature explicitly addresses the spatial dependence problem commonly inherited in housing prices. The neglect of the spatial dependence can result in biased or inefficient estimates. The objectives of this paper are to explore how different types of revitalization with different mixed land uses on housing prices in the immediate neighborhoods via a spatial hedonic pricing model.

With respect to a pre-post hedonic price model, there has been some literature examining the effect of transportation improvement on housing or land prices. In using a pre-post design, McDonald and Osuji (1995) found that residential land values anticipated the construction of the Southwest Rapid Transit Line from downtown Chicago to Midway Airport. Henneberry (1998) followed a similar approach to analyze the impacts of the Supertram (a light-rail line in Sheffield, England) on housing prices. 
He found that anticipation of construction of a light-rail line reduced housing prices during the construction periods. However, the negative impacts were offset by the benefits of a light-rail line when the system was built. The results suggest that it may take longer for the benefits of the system to be fully capitalized into housing prices. In exploring the impacts of the light rail MAX system in Portland, Oregon, Knaap et al (2001) provided a similar evidence that post announcement land prices were $31 \%$ higher within a half-mile of a station and $10 \%$ higher within one mile even though distance has no impact before the announcement. Bae et al (2003) investigated when the construction of a new subway line began to influence the price of condominium in Seoul. Their fining suggest that distance from a subway station had a significant effect on the price of condominium only before the system was completed. This paper also employs a pre-post design to test whether the announcement of the New Town project has an anticipatory effect on housing prices.

\subsection{Research Context}

Regional disparity within the metropolitan areas of Seoul is one of the challenging problems for the Seoul metropolitan government. Seoul has a deepening disparity between distressed old areas and newly-developed areas in terms of residential environment, education, finance, and industrial economy. A huge regional disparity consequently leads to gaps in housing prices and residential neighborhoods, especially between the northern less developed and the southern newly developed areas of the River Han. Although more than 80 percent of newly constructed housing from 2001 to 2003 are located in the northern and southwest districts, many indicators of housing market still 
reveal differences among intra-city districts. For example, the southern districts experience the highest ratio of housing stock to households while the northern districts have the highest rate of dilapidated houses. The Seoul government has been committed to gradually reducing the regional imbalance by redeveloping intra-city districts such as building a complex of condominium, improving public transits and amenities.

In October 2002 and March 2003, the Seoul metropolitan government announced the New Town project which redevelops 15 residential areas based on mixed land uses in the less developed districts in Seoul. The New Town project reflects New Urbanism which advocates a full range of urban settings to provide compact development. The New Town project constitute an effort to transform distressed areas into more diverse, compact, transit friendly, and mixed land use neighborhoods. The total areas of the New Town redevelopment are 3,234 acres. As Figure 4.1 shows, most of the redevelopment areas are located in the northern areas of the River Han. While the scale of each redevelopment area varies in terms of the number of housing units, the types of redevelopment are two kinds of mixed land uses. In a broad context, land development is used four categories: residential, open space, commercial, and basic infrastructure such as roads and school. The land development process is discussed in the following paragraph. The shares of residential and basic infrastructure uses approximately ranges from 60 to 65 percent, and from 10 to 13 percent, respectively. The rest of share depends on the mix of residential with commercial or open space uses. The New Town redevelopment has been announced to have two different types based on how residential use is mixed with commercial and open space uses. Three areas are developed by mixing residential mainly 


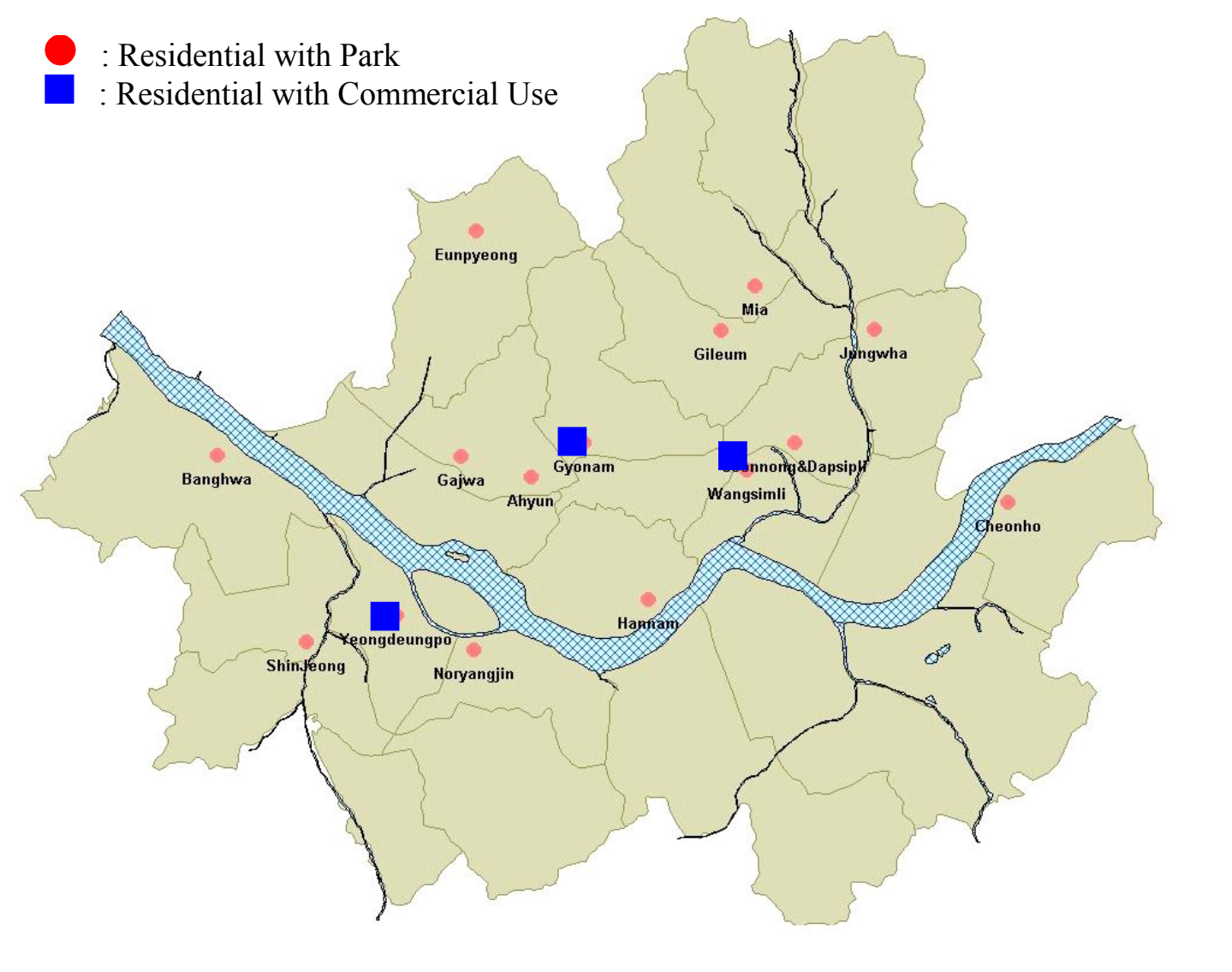

Figure 4.1 Areas of the New Town Project in Seoul.

with open space such as a public park, the share of open space ranging from about 25 to 30 percent. The rest of the areas contain a mixture of residential and more commercial uses. In this case, the shares of commercial and open space range from 15 to 20 percent, 5 to 7 percent, respectively.

The New Town project is different from public housing production programs for neighborhood revitalization in terms of housing types. A large number of housing units built by the New Town project are owner-occupied houses. For example, the public rental housing units will be about 22 percent of the total housing construction in Wangsimli 
where mixes residential with commercial uses. Even though the share of the rental housing units varies among the New Town redevelopment sites, the majority of housing construction is owner-occupied houses.

The reason for building owner-occupied houses is that land use is in complete control of government in Korea. Because of land-use regulations, land use is in complete control of government in South Korea. Therefore, a government is directly involved in land development for residential, commercial, and industrial uses. Inner-city redevelopment is controlled by the Urban Planning Act. This residential land development procedure consists of several stages. The first stage involves making a residential land development plan by the Seoul metropolitan government. Development plans for each potential site are presented to the Ministry of Construction and Transportation (MOCT). MOCT publicly announces the designated land development site, including the construction specifics, time table, and compensation packages, after all negotiations have been concluded. Land in a site designated for development may not be sold between two private parties. Only other public developers can purchase land designated for development. After being purchased by public developers, the site is rezoned for residential, commercial, or public uses such as schools, parks, and greenspace. The basic role of public developers is installation of the basic infrastructure such as roads, parks, electricity, communications services, water supplies and drainage, and cultural and educational facilities. Land designated for public use typically includes the initial offering price for the land is based on appraisals by government authorized appraisal institutions, such as the Korea Appraisal Board. The final stage in the land conversion and development process involves the sale of the land (with infrastructure 
already in place) to construction companies will build on the plot—-this is determined by the plan in stage one.

In general, homeowners have the greater incentives to maintain their homes and higher income neighborhoods. Similarly, homeowners may be more involved in local organizations and activities to improve their community because homeowners tend to live in their homes longer. Therefore, homeownership may have greater neighborhood spillovers on housing prices. (Dipasquale and Glaser, 1999)

Construction of each area will be completed between 2008 and 2012. It is anticipated that the construction of new residential areas can improve the physical and social conditions of neighborhoods such as improved physical appearance of condominium complex, enhanced schools, and increased commercial activity. Therefore, it is expected that the New Town construction will generate spillovers on nearby properties before the project is completed.

\subsection{Data}

The housings in question are condominiums which are 15-25 stories built in multiblock complexes. These housing types have become more typical in Seoul. The ratio of condominiums to all the housing stock is 51.3 percent in 2000 . The housing price data in this study are from the Real Estate 114 for the years 2002 and 2005. This company conducts a considerable survey of condominium market through thousands of local realtors every week. 1890 observations are used for empirical analysis in this paper.

The survey collects data on housing prices, structure characteristics, accessibilities to subway and amenities. The data on housing prices are not the prices of 
Table 4.1

Description and Summary Statistics of Variables

\begin{tabular}{|c|c|c|c|c|c|}
\hline Variable & Description & Mean & $\begin{array}{l}\text { Std. } \\
\text { dev. }\end{array}$ & Minimum & Maximum \\
\hline HP & $\begin{array}{lr}\text { Dependent variable, natural log of house } \\
\text { price: (million Won) } \\
\end{array}$ & $\begin{array}{l}278.27 \\
380.53\end{array}$ & $\begin{array}{l}183.90 \\
292.56\end{array}$ & $\begin{array}{l}56.50 \\
57.00\end{array}$ & $\begin{array}{l}1750.00 \\
2300.00\end{array}$ \\
\hline \multicolumn{6}{|l|}{ Structure Attributes } \\
\hline Age & Age of the house in years: 2002 & 12.45 & 6.78 & 2.00 & 33.00 \\
\hline Floor_Space & Floor space of house in 'pyeong' $\left(3.3 \mathrm{~m}^{2}\right)$ & 25.17 & 10.18 & 6.07 & 69.24 \\
\hline N_Bedroom & Number of bedrooms & 3.03 & 0.91 & 1.00 & 7.00 \\
\hline \multicolumn{6}{|l|}{ Neighborhoods } \\
\hline Pop_Density & $\begin{array}{l}\text { Population density of the Dong where the } \\
\text { house is located (\# of people } / \mathrm{km}^{2} \text { ) }\end{array}$ & 18977.22 & 4948.67 & 7704.90 & 27951.10 \\
\hline School_District & $\begin{array}{l}\text { Dummy variable indicating if the house is } \\
\text { located in Kangnam, Songpa, and Seocho } \\
\text { school district }(1=\text { within })\end{array}$ & & & & \\
\hline D_School & Distance from the nearest school (time) & 13.31 & 8.66 & 2.21 & 35.31 \\
\hline \multicolumn{6}{|l|}{ Accessibility } \\
\hline A_CBD & $\begin{array}{l}\text { Accessibility to the CBD and subcenters } \\
\text { (time) }\end{array}$ & 18.88 & 11.02 & 1.00 & 42.00 \\
\hline A_Subway & $\begin{array}{l}\text { Accessibility to the nearest subway station } \\
\text { (time) }\end{array}$ & 6.54 & 3.54 & 1.00 & 20.00 \\
\hline A_Commercial & $\begin{array}{l}\text { Accessibility to the nearest commercial } \\
\text { shopping store (time) }\end{array}$ & 15.33 & 8.30 & 2.00 & 30.00 \\
\hline A_Park & $\begin{array}{l}\text { Accessibility to the nearest public park } \\
\text { (time) }\end{array}$ & 21.46 & 11.43 & 5.45 & 40.00 \\
\hline \multicolumn{6}{|l|}{ Mixed Land Uses } \\
\hline NT_OpenSpace1 & $\begin{array}{l}\text { Dummy variable indicating the house lies } \\
\text { within one-km zone of the New Town project } \\
\text { site with park }\end{array}$ & & & & \\
\hline NT_OpenSpace2 & $\begin{array}{l}\text { Dummy variable indicating the house lies } \\
\text { within one to two km zone of the New Town } \\
\text { project site with park }\end{array}$ & & & & \\
\hline NT_OpenSpace3 & $\begin{array}{l}\text { Dummy variable indicating the house lies } \\
\text { within two to three km zone of the New } \\
\text { Town project site with park }\end{array}$ & & & & \\
\hline NT_Com 1 & $\begin{array}{l}\text { Dummy variable indicating the house lies } \\
\text { within one-km zone of the New Town project } \\
\text { site with commercial }\end{array}$ & & & & \\
\hline NT_Com2 & $\begin{array}{l}\text { Dummy variable indicating the house lies } \\
\text { within one-to-two km zone of the New Town } \\
\text { project site with commercial }\end{array}$ & & & & \\
\hline NT_Com3 & $\begin{array}{l}\text { Dummy variable indicating the house lies } \\
\text { within two-to- three km zone of the New } \\
\text { Town project site with commercial }\end{array}$ & & & & \\
\hline
\end{tabular}

${ }^{\mathrm{a}}$ Won is the Korean currency; $\$ 1$ is approximately 1050 won. 
housing sold. The housing prices are based on respondent estimates. These estimates can be considered reasonably accurate given the institutional characteristics of the Seoul market. The data on above are available on the Website of many real estate companies. Furthermore, the structure characteristics of condominium tend to be very similar even in the different areas. The Korean government has also adopted a system of posted housing prices for property tax collection. Therefore, it is widely held opinion that respondent estimates of local realtors can represent the value of condominium. Since respondent estimates consist of minimum and maximum values for each unit, this paper uses the average for each unit.

The variables used to estimate the spatial hedonic model are described in Table 4.1. The dependent variable, housing prices, is deflated using the Consumer Price Index for housing for the year in which the survey was conducted.

The physical housing attributes entering the spatial hedonic model as explanatory variables are the total floor space of the house (expressed in pyeong, the conventional unit in Korea equal to $3.3 \mathrm{~m}^{2}$ or $32.5 \mathrm{ft}^{2}$ ), the number of bedrooms, and the age of the house at the time of survey.

The neighborhood characteristics fall into three categories: area population density, and school districts. It is common perception that a homeowner with high-school children has a strong preference for a housing unit in a $\operatorname{good}^{11}$ high school district. Kangnam, Seocho, and Songpa districts are called Kangnam 8 Education District since most of the good schools are located in those districts. This common perception partially

\footnotetext{
${ }^{11}$ A formal ranking of high schools in Korea is not available. However, the scores of college entrance examination are widely used to rank high schools in Korea. Choi (2004) presented evidence that the number of students with high scores is three times more from the high schools located Kangnam 8 Education District than elsewhere.
} 
explains why this paper uses school district a neighborhood variable. In addition to a binary variable for good high school districts, this paper includes distance from the house to any nearest school including elementary school because public services within the neighborhood affect housing values.

To measure the property's accessibility, four variables are used. Since the subway system has recently had about 5.4 million daily riders out of 10.3 million total population in Seoul, distance from a subway station is a key variable for accessibility to transportation. Another accessibility variable is distance from the central business district (CBD) and from other two major subcenters, Kangnam and Yeouido. Sine the data from Real Estate 114 does not contain information about distance from the house to the CBD, it is indirectly calculated. The maximum and average walking distances from the house's nearest subway station are 20 minutes and 7 minutes, respectively. Furthermore, more than 50 percent total population in Seoul uses the subway. Under these circumstances, it is plausible that approximate distance from the $\mathrm{CBD}$ is calculated by time from the $\mathrm{CBD}$ to the house's nearest subway station. Walkable communities mixing residential and nonresidential land uses have been considered as more desirable places to live. To investigate how the homeowners respond to different mixed land uses, this paper includes two variables of accessibility to non-residential land use: distance to the nearest commercial store or public park.

Finally, the spatial hedonic model includes two sets of dummy variables which indicate whether the house is within a given contour ring from the nearest New Town project site. These distance contours are within one kilometer from the nearest New 
Table 4.2

Average growth rate of housing prices

\begin{tabular}{llllll}
\hline & $2002 \sim 2003$ & $2003 \sim 2004$ & $2004 \sim 2005$ & $2002 \sim 2005$ & $2003 \sim 2005$ \\
\hline NT_OpenSpace1 & $\begin{array}{l}13.72 \\
(8.94)\end{array}$ & $\begin{array}{l}11.00^{* *} \\
(8.69)\end{array}$ & $\begin{array}{l}0.50 \\
(4.88)\end{array}$ & $\begin{array}{l}25.69^{*} \\
(18.20)\end{array}$ & $\begin{array}{l}13.61^{* * *} \\
(10.90)\end{array}$ \\
NT_OpenSpace2 & 13.28 & 12.99 & 0.05 & $27.23^{* * *}$ & $12.05^{* *}$ \\
& $(6.58)$ & $(10.74)$ & $(4.44)$ & $(17.06)$ & $(12.09)$ \\
NT_OpenSpace3 & 14.17 & $8.87^{* * *}$ & 0.01 & 22.36 & $7.40^{* * *}$ \\
& $(7.83)$ & $(7.00)$ & $(4.27)$ & $(12.17)$ & $(10.26)$ \\
NT_Com1 & 15.72 & 14.98 & $3.50^{* * *}$ & $32.43 * * *$ & $15.57^{*}$ \\
& $(7.70)$ & $(5.22)$ & $(3.28)$ & $(10.73)$ & $(6.10)$ \\
NT_Com2 & 16.77 & 13.17 & $1.86^{* *}$ & $29.07 * *$ & 11.23 \\
& $(7.29)$ & $(6.82)$ & $(4.93)$ & $(15.09)$ & $(9.24)$ \\
NT_Com3 & $14.42^{* *}$ & $7.64 * * *$ & 0.09 & $24.76^{*}$ & $8.77^{* * *}$ \\
& $(7.83)$ & $(7.00)$ & $(4.27)$ & $(12.17)$ & $(10.26)$ \\
Rest of Seoul & 14.20 & 12.76 & -0.08 & 23.29 & 10.02 \\
& $(7.52)$ & $(12.00)$ & $(5.96)$ & $(17.57)$ & $(12.03)$ \\
\hline
\end{tabular}

Note: The parenthesis is standard deviation. The test for whether the growth rate of each contour is statistically different from that of the rest of Seoul is conducted: ${ }^{* * *}, p<0.01 ;{ }^{* *}, p<0.05 ;{ }^{*}, p<0.1$.

Town project site, between one kilometer and two kilometers, and two to three kilometers. This paper uses a set of dummy variables for each type of mixed land uses because the New Town project consists of two different types of mixed land uses: residential use with open space and residential use with commercial use.

Table 4.2 shows the average growth rate of housing prices at different distances from the New Town redevelopment area. Overall, housing prices have grown faster within every zone of the New Town redevelopment area than in the rest of the city from 2002 to 2005 , except within two to three kilometers of the New Town redevelopment area with commercial uses. In addition, housing prices have grown greater in the proximity to redevelopment with commercial uses. The biggest growth rate has happened 
within one-kilometer zone of the New Town redevelopment project with commercial uses. Another interesting fact is that housing prices have increased in the neighboring areas of the New Town redevelopment while the rest of the city has experienced decrease in housing prices between 2004 and 2005.

\subsection{The Spatial Hedonic Pricing Models}

The purpose of this paper is to explore whether redevelopment of the distressed neighborhoods have spillovers on housing prices in surrounding neighborhoods. Furthermore, this study is extended to analyze how consumers respond to the different type of revitalization with different mixed land uses. It is widely accepted that housing prices tend to exhibit the spatial dependence. A theoretical motivation for spatial dependence in a housing price analysis arises from the fact that consumers in a neighborhood may imitate each other leading to spatial dependence. From a statistical standpoint, housing prices are collected at spatial locations. It seems likely that housing prices may display spatial dependence arising from spatially correlated unobservable or difficult-to-quantify variables (Lesage, 1999). Therefore, it is important to take account of the possibility of spatial dependence between observations. Surprisingly, not much of the literature for neighborhood spillovers have taken spatial issues into account.

There are two types of spatial dependence: an autoregressive residual pattern due to the omission of a spatial lag or a nuisance type of spatial dependence similar to serial correlation. Corresponding to the types, two ways can be considered to incorporate spatial effects into a regression model: as an additional regressor in the form of a spatially lagged dependent variable (the spatial lag model) or in the regression disturbance term 
(the spatial error model). A general spatial autoregressive model has been introduced in (4.1) below (Anselin, 1988):

$$
\begin{aligned}
& \mathrm{y}=\rho \mathrm{W}_{1} \mathrm{y}+\mathrm{X} \beta+u \\
& u=\lambda \mathrm{W}_{2} u+\varepsilon \\
& \varepsilon \sim N\left(0, \sigma^{2} I_{n}\right)
\end{aligned}
$$

where $\mathrm{y}$ is an $\mathrm{n} \times 1$ column vector of dependent variables and $\mathrm{X}$ represents an $\mathrm{n} \times \mathrm{k}$ matrix of exogenous variables. $\mathrm{W}_{1}$ and $\mathrm{W}_{2}$ are known $\mathrm{n} \times \mathrm{n}$ spatial weight matrices that typically measure contiguity relations or functions of distance. The spatial weight matrices in this study are based on a notion of distance decay. The spatial weight matrices contain nonzero elements in those row-column combinations corresponding to observational units that are assumed to interact. The diagonal elements of the weights matrices are set to zero and row elements are standardized such that they sum to one. $\mathrm{W}_{1} \mathrm{y}$ is an explanatory variable representing an average of spatially neighboring values. $\rho$ is a coefficient vector that measures the effect of neighboring units on the dependent variable. $\lambda$ is a vector measuring spatial autocorrelation in the disturbance term.

The spatial lag model is appropriate when the focus of interest is the assessment of the existence and strength of spatial interaction. Therefore, this specification is a relevant tool to analyze neighborhood spillovers because an average of spatially neighboring housing prices, $\mathrm{W}_{1} \mathrm{y}$, enters as an explanatory variable in the specification. This specification also allows us to measure the net effect of the explanatory variables after the spatial autocorrelation is corrected. Consequently, ordinary least-square (OLS) estimators are biased and inconsistent due to the endogeneity in the spatial lag term, $\mathrm{W}_{1} \mathrm{y}$, in the spatial lad model. Therefore, the spatial lag term must be treated as an endogenous 
variable and proper estimation methods need to be employed to obtain consistent estimators.

The spatial error model is appropriate when the modeler uses spatial data and is concerned about correcting for the potentially biasing influence of the spatial autocorrelation (Anselin, 2001). There may be no underlying theoretical motivation for spatial dependence in the spatial error model. Spatial dependence may arise here when the variables are collected from spatial locations that do not accurately reflect neighborhoods (LeSage, 1999). Consequently, the OLS estimator remains unbiased but no longer efficient in the spatial error model similar to the case of serial correlation problem. In a regression context and from a methodological standpoint, the general spatial model is suggested when there is evidence that spatial dependence exists in the error term from the spatial lag model (Lesage, 1999).

This paper exploits a spatial hedonic price model to explore the effects on housing prices of redevelopment neighborhood spillovers with different mixed land uses by correcting spatial dependence problems. The general spatial hedonic price model can be written with a semilog specification as follows:

$$
\begin{aligned}
& \operatorname{lnHP}=\rho \mathrm{W}_{1} \operatorname{lnHP}+\mathrm{X}_{1} \beta_{1}+\mathrm{X}_{2} \beta_{2}+\mathrm{X}_{3} \beta_{3}+\mathrm{NT} \_ \text {OpenSpace } \beta_{4}+\mathrm{NT}_{-} \operatorname{Com} \beta_{5}+u \\
& u=\lambda \mathrm{W}_{2} u+\varepsilon
\end{aligned}
$$

where HP is the vector of housing prices, $\mathrm{X}_{1}$ is a matrix with observations on structural characteristics, $\mathrm{X}_{2}$ is a matrix with observations on neighborhood characteristics, $\mathrm{X}_{3}$ is a matrix with observations on accessibility characteristics, NT_OpenSpace is a matrix reflecting observations within each contour of the New Town redevelopment with parks, and NT_Com is a matrix with observations within each contour of the New Town 
redevelopment with commercial uses. The distinction of the New Town redevelopments between with parks and commercial uses can allow us to capture how households value differences in the characteristics of neighborhood form: residential areas with parks or commercial stores.

One of the purposes in this paper is to examine when the effects of redevelopment neighborhood spillovers are likely to appear. To investigate how neighborhood spillover effects change over time, this paper exploits a pre-post approach which allows us to estimate the effects of redevelopment plan on housing prices by controlling for other possible influences on housing prices.

Before the announcement of the New Town project, housing prices takes the form shown in (4.3):

$$
\begin{aligned}
\operatorname{lnHP}_{\mathrm{b}} & =\rho_{b} \mathrm{~W}_{1 \mathrm{~b}} \operatorname{lnHP}_{\mathrm{b}} \\
& +\mathrm{X}_{1 \mathrm{~b}} \beta_{1 \mathrm{~b}}+\mathrm{X}_{2 \mathrm{~b}} \beta_{2 \mathrm{~b}}+\mathrm{X}_{3 \mathrm{~b}} \beta_{3 \mathrm{~b}} \\
& +\mathrm{NT} \_ \text {OpenSpace } \beta_{4 \mathrm{~b}}+\mathrm{NT}_{-} \mathrm{Com}_{\mathrm{b}} \beta_{5 \mathrm{~b}} \\
& +u_{b} \\
u_{b}= & \lambda_{b} \mathrm{~W}_{2 b} u_{b}+\varepsilon_{b}
\end{aligned}
$$

where the ' $b$ ' subscript attached to variables represents to the values of the variables in the 'before' period, $\rho_{\mathrm{b}}$ through $\lambda_{\mathrm{b}}$ are coefficients in the 'before' period. Since the New Town redevelopment areas are distressed, it is expected that housing prices tend to decrease in the immediate areas before the information about the redevelopment plan is announced.

The equation for housing prices after the New Town project is fully known is demonstrated (4.4) below: 


$$
\begin{aligned}
\operatorname{lnHP}_{\mathrm{a}} & =\rho_{a} \mathrm{~W}_{1 \mathrm{a}} \ln \mathrm{HP}_{\mathrm{a}} \\
& +\mathrm{X}_{1 \mathrm{a}} \beta_{1 \mathrm{a}}+\mathrm{X}_{2 \mathrm{a}} \beta_{2 \mathrm{a}}+\mathrm{X}_{3 \mathrm{a}} \beta_{3 \mathrm{a}} \\
& +\mathrm{NT}_{-} \text {OpenSpace } \beta_{\mathrm{a}} \beta_{4 \mathrm{a}}+\mathrm{NT}_{-} \operatorname{Com}_{\mathrm{a}} \beta_{5 \mathrm{a}} \\
& +u_{a} \\
u_{a}= & \lambda_{a} \mathrm{~W}_{2 a} u_{a}+\varepsilon_{a}
\end{aligned}
$$

where the 'a' subscript attached to the variables and coefficients refers to the 'after' period. Since the plan of the New Town Project was announced in October, 2002 and November, 2003, the data collected in March, 2002 and 2005 are taken as the 'before' and 'after' time periods, respectively. 2004 might be too early to capture the impacts of the announcement. However, the empirical results for 2004 will be given in an Appendix.

A pre-post approach represented by Equations (4.4) and (4.5) allows all variables to have different effects on housing prices in the two periods. $\left(\beta_{4 \mathrm{a}}-\beta_{4 \mathrm{~b}}\right)$ and $\left(\beta_{5 \mathrm{a}}-\beta_{5 \mathrm{~b}}\right)$ measure the net effects of each type of the New Town redevelopment with different mixed land uses on housing prices in percentage term because those represent the changes in the effect of proximity to the New Town redevelopment areas.

\subsection{Results}

The existence of spatial dependence in the model leads OLS estimators to be inconsistent or inefficient. Therefore, among the estimation used for spatial regression models, maximum likelihood estimation has been predominant. Three spatial hedonic price models in this paper are estimated by maximum likelihood approach. Table 4.3 and 4.4 show the empirical results of the ordinary least squares (OLS) and the three spatial autoregressive models for 2002 and 2005, respectively. Table 4.3 and 4.4 show that all variables demonstrate similar results in two periods, except for the dummy variables 
Table 4.3 Estimation Results for 2002

\begin{tabular}{|c|c|c|c|c|}
\hline Variable & OLS & SAR & SEM & GSAR \\
\hline$\rho$ & & $\begin{array}{l}0.101^{* *} \\
(2.32)\end{array}$ & & $\begin{array}{l}0.019^{*} \\
(1.85)\end{array}$ \\
\hline$\lambda$ & & & $\begin{array}{l}0.574 * * * \\
(2.82)\end{array}$ & $\begin{array}{l}0.590^{* * *} \\
(12.28)\end{array}$ \\
\hline Constant & $\begin{array}{l}-1.072^{* * *} \\
(-12.86)\end{array}$ & $\begin{array}{l}-1.057 * * * \\
(-15.37)\end{array}$ & $\begin{array}{l}-1.018^{* * *} \\
(-17.27)\end{array}$ & $\begin{array}{l}-1.030^{* * *} \\
(-15.16)\end{array}$ \\
\hline Age & $\begin{array}{l}-0.171 * * * \\
(-11.10)\end{array}$ & $\begin{array}{l}-0.172 * * * \\
(-29.44)\end{array}$ & $\begin{array}{l}-0.171 * * * \\
(-31.72)\end{array}$ & $\begin{array}{l}-0.170 * * * \\
(-29.98)\end{array}$ \\
\hline Age_Square & $\begin{array}{l}0.014 * * * \\
(12.11)\end{array}$ & $\begin{array}{l}0.014 * * * \\
(68.10)\end{array}$ & $\begin{array}{l}0.014 * * * \\
(70.40)\end{array}$ & $\begin{array}{l}0.014 * * * \\
(68.24)\end{array}$ \\
\hline Age_Cubed & $\begin{array}{l}-0.0003 * * * \\
(-12.21)\end{array}$ & $\begin{array}{l}-0.0003 * * * \\
(-512.69)\end{array}$ & $\begin{array}{l}-0.0003 * * * \\
(-440.02)\end{array}$ & $\begin{array}{l}-0.0003 * * * \\
(-464.64)\end{array}$ \\
\hline Floor_Space & $\begin{array}{l}0.053 * * * \\
(23.41)\end{array}$ & $\begin{array}{l}0.052 * * * \\
(23.55)\end{array}$ & $\begin{array}{l}0.053 * * * \\
(26.29)\end{array}$ & $\begin{array}{l}0.054 * * * \\
(24.74)\end{array}$ \\
\hline N_Bedroom & $\begin{array}{l}0.124^{* * *} \\
(4.94)\end{array}$ & $\begin{array}{l}0.120^{* * * *} \\
(4.86)\end{array}$ & $\begin{array}{l}0.123^{* * *} \\
(5.50)\end{array}$ & $\begin{array}{l}0.116^{* * * *} \\
(4.84)\end{array}$ \\
\hline PopDensity & $\begin{array}{l}0.088^{* * *} \\
(7.31)\end{array}$ & $\begin{array}{l}0.089 * * * \\
(0.09)\end{array}$ & $\begin{array}{l}0.107 * * * \\
(9.16)\end{array}$ & $\begin{array}{l}0.101^{* * *} \\
(8.11)\end{array}$ \\
\hline School_District & $\begin{array}{l}0.659 * * * \\
(20.51)\end{array}$ & $\begin{array}{l}0.640^{* * *} \\
(21.62)\end{array}$ & $\begin{array}{l}0.687^{* * * *} \\
(21.59)\end{array}$ & $\begin{array}{r}0.674 * * * \\
(20.86)\end{array}$ \\
\hline D_School & $\begin{array}{l}-0.019^{* * *} \\
(-4.19)\end{array}$ & $\begin{array}{l}-0.018^{* * *} \\
(-4.12)\end{array}$ & $\begin{array}{l}-0.017^{* * *} \\
(-4.04)\end{array}$ & $\begin{array}{l}-0.016^{* * *} \\
(-3.82)\end{array}$ \\
\hline A_CBD & $\begin{array}{l}-0.022^{* * *} \\
(-20.51)\end{array}$ & $\begin{array}{l}-0.022^{* * *} \\
(-20.81)\end{array}$ & $\begin{array}{l}-0.023^{* * *} * \\
(-20.65)\end{array}$ & $\begin{array}{l}-0.023^{* * *} \\
(-20.22)\end{array}$ \\
\hline A_Subway & $\begin{array}{l}-0.016^{* * *} \\
(-5.28)\end{array}$ & $\begin{array}{l}-0.015^{* * *} \\
(-5.15)\end{array}$ & $\begin{array}{l}-0.014 * * * \\
(-5.07)\end{array}$ & $\begin{array}{l}-0.014 * * * \\
(-4.93)\end{array}$ \\
\hline A_Commercial & $\begin{array}{l}-0.037^{* * *} \\
(-6.83)\end{array}$ & $\begin{array}{l}-0.037^{* * *} \\
(-6.91)\end{array}$ & $\begin{array}{l}-0.032^{* * * *} \\
(-6.54)\end{array}$ & $\begin{array}{l}-0.032^{* * *} \\
(-6.07)\end{array}$ \\
\hline A_Park & $\begin{array}{l}-0.002 \\
(-0.15) \\
\end{array}$ & $\begin{array}{l}-0.002 \\
(-0.17) \\
\end{array}$ & $\begin{array}{l}-0.002 \\
(-0.15) \\
\end{array}$ & $\begin{array}{l}-0.002 \\
(-0.12)\end{array}$ \\
\hline NT_OpenSpace1 & $\begin{array}{l}-0.205^{* * *} \\
(-5.82)\end{array}$ & $\begin{array}{l}-0.204 * * * \\
(-5.88)\end{array}$ & $\begin{array}{l}-0.217^{* * *} \\
(-6.12)\end{array}$ & $\begin{array}{l}-0.216^{* * *} \\
(-6.04)\end{array}$ \\
\hline NT_ OpenSpace2 & $\begin{array}{l}0.021 \\
(0.61)\end{array}$ & $\begin{array}{l}0.023 \\
(0.66)\end{array}$ & $\begin{array}{l}0.021 \\
(0.61) \\
\end{array}$ & $\begin{array}{l}0.021 \\
(0.60)\end{array}$ \\
\hline NT__openSpace3 & $\begin{array}{l}-0.002 \\
(-0.07)\end{array}$ & $\begin{array}{l}-0.003 \\
(-0.09)\end{array}$ & $\begin{array}{l}-0.040 \\
(-1.36)\end{array}$ & $\begin{array}{l}-0.038 \\
(-1.22)\end{array}$ \\
\hline NT_Com1 & $\begin{array}{l}-0.481^{* * * *} \\
(-4.17)\end{array}$ & $\begin{array}{l}-0.478^{* * * *} \\
(-4.18)\end{array}$ & $\begin{array}{l}-0.468^{* * *} \\
(-4.22)\end{array}$ & $\begin{array}{l}-0.455^{* * *} \\
(-4.09)\end{array}$ \\
\hline NT_Com2 & $\begin{array}{l}-0.093 \\
(-1.39) \\
\end{array}$ & $\begin{array}{l}-0.097 \\
(-1.46)\end{array}$ & $\begin{array}{l}-0.059 \\
(-0.89) \\
\end{array}$ & $\begin{array}{l}-0.061 \\
(-0.90)\end{array}$ \\
\hline NT_Com3 & $\begin{array}{l}0.063 \\
(0.74) \\
\end{array}$ & $\begin{array}{l}0.052 \\
(0.12)\end{array}$ & $\begin{array}{l}0.036 \\
(0.43) \\
\end{array}$ & $\begin{array}{l}0.039 \\
(0.46)\end{array}$ \\
\hline $\mathrm{R}^{2}$ & 0.83 & 0.83 & 0.84 & 0.84 \\
\hline LM & $277.8^{* * *}$ & $251.1^{* * *}$ & & \\
\hline Observations & 1890 & 1890 & 1890 & 1890 \\
\hline
\end{tabular}

Note: The parenthesis is t value; ${ }^{* *}, \mathrm{p}<0.01 ;{ }^{* *}, \mathrm{p}<0.05 ;{ }^{*}, \mathrm{p}<0.1$. 
Table 4.4 Estimation Results for 2005

\begin{tabular}{|c|c|c|c|c|}
\hline Variable & OLS & SAR & SEM & GSAR \\
\hline$\rho$ & & $\begin{array}{l}0.106^{* * * *} \\
(2.70)\end{array}$ & & $\begin{array}{l}0.047 * * * \\
(2.94)\end{array}$ \\
\hline$\lambda$ & & & $\begin{array}{l}0.640 * * * \\
(14.24)\end{array}$ & $\begin{array}{l}0.570 * * * \\
(2.98)\end{array}$ \\
\hline Constant & $\begin{array}{l}-1.079 * * * \\
(-19.04)\end{array}$ & $\begin{array}{l}-1.062^{* * *} \\
(-19.80)\end{array}$ & $\begin{array}{l}-1.033^{* * *} \\
(-19.48)\end{array}$ & $\begin{array}{l}-1.000 * * * \\
(-25.74)\end{array}$ \\
\hline Age & $\begin{array}{l}-0.143 * * * \\
(-8.78)\end{array}$ & $\begin{array}{l}-0.144 * * * \\
(-16.19)\end{array}$ & $\begin{array}{l}-0.137 * * * \\
(-16.16)\end{array}$ & $\begin{array}{l}-0.140^{* * *} \\
(-18.02)\end{array}$ \\
\hline Age_Square & $\begin{array}{l}0.010^{* * *} \\
(10.75)\end{array}$ & $\begin{array}{l}0.010^{* * *} \\
(42.57)\end{array}$ & $\begin{array}{l}0.010^{* * *} \\
(41.93)\end{array}$ & $\begin{array}{l}0.010^{* * *} \\
(44.14)\end{array}$ \\
\hline Age_Cubed & $\begin{array}{l}-0.0002^{* * *} \\
(-10.10)\end{array}$ & $\begin{array}{l}-0.0002^{* * *} \\
(-301.36)\end{array}$ & $\begin{array}{l}-0.0002 * * * \\
(-264.12)\end{array}$ & $\begin{array}{l}-0.0002^{* * *} \\
(-250.08)\end{array}$ \\
\hline Floor_Space & $\begin{array}{l}0.053^{* * *} \\
(24.47)\end{array}$ & $\begin{array}{l}0.052^{* * *} \\
(24.83)\end{array}$ & $\begin{array}{l}0.053 * * * \\
(26.18)\end{array}$ & $\begin{array}{l}0.053 * * * \\
(27.91)\end{array}$ \\
\hline N_Bedroom & $\begin{array}{l}0.077 * * * \\
(3.13)\end{array}$ & $\begin{array}{l}0.075^{* * *} \\
(3.11)\end{array}$ & $\begin{array}{l}0.075^{* * *} \\
(3.24)\end{array}$ & $\begin{array}{l}0.077 * * * \\
(3.59)\end{array}$ \\
\hline PopDensity & $\begin{array}{l}0.112^{* * *} \\
(8.99)\end{array}$ & $\begin{array}{l}0.113^{* * *} \\
(9.21)\end{array}$ & $\begin{array}{l}0.126^{* * *} \\
(9.83)\end{array}$ & $\begin{array}{l}0.131 * * * \\
(10.90)\end{array}$ \\
\hline School_District & $\begin{array}{l}0.715^{* * *} \\
(21.19)\end{array}$ & $\begin{array}{l}0.694 * * * \\
(-21.89)\end{array}$ & $\begin{array}{l}0.731 * * * \\
(-21.33)\end{array}$ & $\begin{array}{l}0.737 * * * \\
(21.88)\end{array}$ \\
\hline D_School & $\begin{array}{l}-0.016^{* * *} \\
(-3.35)\end{array}$ & $\begin{array}{l}-0.016^{* * *} \\
(-3.28)\end{array}$ & $\begin{array}{l}-0.014 * * * \\
(-2.94)\end{array}$ & $\begin{array}{l}-0.014 * * * \\
(-3.18)\end{array}$ \\
\hline A_CBD & $\begin{array}{l}-0.021 * * * \\
(-18.50)\end{array}$ & $\begin{array}{l}-0.021 * * * \\
(-18.48)\end{array}$ & $\begin{array}{l}-0.022 * * * \\
(-19.25)\end{array}$ & $\begin{array}{l}-0.022^{* * *} \\
(-21.33)\end{array}$ \\
\hline A_Subway & $\begin{array}{l}-0.012^{* * *} \\
(-3.70)\end{array}$ & $\begin{array}{l}-0.011 * * * \\
(-3.52)\end{array}$ & $\begin{array}{l}-0.011 * * * \\
(-3.60)\end{array}$ & $\begin{array}{l}-0.011^{* * *} \\
(-3.83)\end{array}$ \\
\hline A_Commercial & $\begin{array}{l}-0.038^{* * *} \\
(-6.56)\end{array}$ & $\begin{array}{l}-0.038^{* * *} \\
(-6.65)\end{array}$ & $\begin{array}{l}-0.032 * * * \\
(-5.85)\end{array}$ & $\begin{array}{l}-0.032^{* * *} \\
(-6.16)\end{array}$ \\
\hline A_Park & $\begin{array}{l}-0.008 \\
(-0.53)\end{array}$ & $\begin{array}{l}-0.008 \\
(-0.55)\end{array}$ & $\begin{array}{l}-0.005 \\
(-0.36)\end{array}$ & $\begin{array}{l}-0.007 \\
(-0.48)\end{array}$ \\
\hline NT_OpenSpace1 & $\begin{array}{l}-0.046 \\
(-1.14)\end{array}$ & $\begin{array}{l}-0.048 \\
(-1.18)\end{array}$ & $\begin{array}{l}-0.026 \\
(-0.62)\end{array}$ & $\begin{array}{l}-0.048 \\
(-1.16)\end{array}$ \\
\hline NT_OpenSpace2 & $\begin{array}{l}0.028 \\
(0.80)\end{array}$ & $\begin{array}{l}0.030 \\
(0.85)\end{array}$ & $\begin{array}{l}0.037 \\
(1.04)\end{array}$ & $\begin{array}{l}0.038 \\
(1.08)\end{array}$ \\
\hline NT_OpenSpace3 & $\begin{array}{l}-0.004 \\
(-0.12)\end{array}$ & $\begin{array}{l}-0.006 \\
(-0.17)\end{array}$ & $\begin{array}{l}-0.026 \\
(-0.82)\end{array}$ & $\begin{array}{l}-0.035 \\
(-1.14)\end{array}$ \\
\hline NT_Com1 & $\begin{array}{l}-0.138 \\
(-1.01)\end{array}$ & $\begin{array}{l}-0.150 \\
(-1.11)\end{array}$ & $\begin{array}{l}-0.147 \\
(-1.13)\end{array}$ & $\begin{array}{l}-0.155 \\
(-1.19)\end{array}$ \\
\hline NT_Com2 & $\begin{array}{l}0.050 \\
(0.63)\end{array}$ & $\begin{array}{l}0.045 \\
(0.59)\end{array}$ & $\begin{array}{l}0.093 \\
(1.18)\end{array}$ & $\begin{array}{l}0.073 \\
(0.94)\end{array}$ \\
\hline NT_Com3 & $\begin{array}{l}0.076 \\
(0.84)\end{array}$ & $\begin{array}{l}0.069 \\
(0.77)\end{array}$ & $\begin{array}{l}0.045 \\
(0.51)\end{array}$ & $\begin{array}{l}0.038 \\
(0.44)\end{array}$ \\
\hline $\mathrm{R}^{2}$ & 0.80 & 0.81 & 0.82 & 0.82 \\
\hline LM & $301.7 * * *$ & $293.4 * * *$ & & \\
\hline Observations & 1890 & 1890 & 1890 & 1890 \\
\hline
\end{tabular}

Note: The parenthesis is t value; ${ }^{* *}, \mathrm{p}<0.01 ;{ }^{* *}, \mathrm{p}<0.05 ; *, \mathrm{p}<0.1$. 
regarding the New Town redevelopment project. Most of the coefficients have expected signs.

Even though the results from OLS are very similar to those from the spatial models in the both periods, it is necessary to discuss an analysis of diagnostics for spatial effects. $\rho$ and $\lambda$ are both significant in all the spatial regressions. In addition, the Lagrange multiplier (LM) tests for spatial autocorrelation in the residuals are conducted both for the ordinary least squares, OLS, and the spatial lag model, SAR. Both LM statistics with conventional significance indicate evidence of spatial autocorrelation in the error terms. Since spatial autocorrelation is indeed present in the spatial lag model, SAR, the general spatial autoregressive model (GSAR) is preferred for the interpretation. The R squared measures favor GSAR by providing the largest values. Given the strong evidence of spatial autocorrelation, it is argued that OLS estimates are likely to be biased and inconsistent.

The coefficients of house characteristics variables have the expected signs. Floor space and the number of bedrooms have a positive effect on housing prices. While the anticipated negative sign of age variable indicates that an older house is less valuable than a newer house, the significant coefficients of both Age_Square and Age_Cubed ${ }^{12}$ variables suggest that the relationship between housing price and house age is not linear. The impact of age on housing prices is $0.039^{13}$ and 0.025 for 2002 and 2005, respectively. This is opposite to the anticipated negative sign. However, this result is consistent with that observed by Lee et al (2005). They demonstrated that the aging of a structure has two kinds of effects on housing prices. As house becomes older, it leads to

\footnotetext{
${ }^{12}$ Lee et al (2005) show that nonlinear effects of the age variable on housing prices in the cubed age specifications. This essay follows their methodology.

${ }^{13}$ When evaluated at sample average, $\partial \mathrm{HP} / \partial \mathrm{Age}=-0.170+2(0.014)(12.45)+3(-0.0003)(12.45)^{2}=0.039$
} 
depreciation as well as the possibility of redevelopment. Expectations of redevelopment in the near future and the eventual announcement of redevelopment plans can have a strong positive impact on housing price. According to their result, the depreciation effect dominates the redevelopment effect until 15 to 19 years of age but the redevelopment effect eventually offsets the depreciation effect. The basic reason for this unusual phenomenon might result from land-use regulations. As section 4.3 described the land development process, redevelopment is controlled by government even though condominium is privately owned. When condominium needs to be redeveloped, condominium owners should be compensated. Therefore, the aging of a structure can have both the depreciation and redevelopment effects.

In terms of neighborhood characteristics, population density and the school district variables are significant but the variable of distance from the nearest school is not significant. Surprisingly, housing prices are positively associated with population density. One possibility is suggested for this unexpected sign of population density. The typical house in Seoul has been condominiums which are 15 to 25 stories built in multiblock complexes these days. The share of condominiums in total housing construction in Seoul was 81.5 percent in 2000 . Since inner-city condominium construction is completely controlled by the government, government plans not only include residential construction but also contains the installation of the basic infrastructure and cultural and educational facilities. Consequently, those areas are likely to provide denser and more walkable environments. This indicates that people might prefer living in newly developed areas with condominiums. Myers and Gearin (2001) provided a review of survey evidence that the demand trend for denser and more compact residential areas has been under way. The 
school district variable indicates that districts such as Kangnam, Seocho, and Songpa are much more attractive to households rather than the rest of school districts. The negative sign of the variable D_School with conventional significance confirms that the people have a preference for the house close to a school.

As for accessibility characteristics, location matters. Negative sign of the variable A_CBD indicates that housing prices fall with distance from the CBD and subcenters. As expected, distance from the subway station is negatively related to housing prices. In terms of accessibility to non-residential land uses, only proximity to a commercial shopping center has a positive impact on housing prices while a public park is not significantly attractive to households.

As for neighborhood spillovers of the New Town redevelopment, Table 4.3 and 4.4 provide different results from 'before' (2002) and 'after' (2005) periods. The relationships between housing prices and the variables used to capture the effects of proximity to the New Town project site are significant only for the before period. Dummy variables NT_OpenSpace1 and NT_Com1 are significant in the before time period . However, results provide evidence that housing prices between one and three kilometers were not significantly lower than those elsewhere in 2002. Negative signs of variables, NT_OpenSpace1 and NT_Com1 indicate that houses within one kilometer from the New Town project site have lower value compared to those farther away. These results imply that houses that are close to the distressed New Town project areas were affected by negative neighborhood externalities. However, results from 2005 show that none of coefficients of distance contours from the New Town project sites are significant. 
It suggests that redevelopment plan announcements of the New Town project might exert neighborhood spillovers on the value of surrounding housings.

It is necessary to discuss the anticipatory impact of neighborhood spillovers on intermediate housing prices by comparing the magnitude of coefficients from 2002 and 2005. The results from GSAR imply that the redevelopment plan announcement generates a net increase of $18.2 \%{ }^{14}$ in housing prices within one kilometer of the New Town project site with residential use and open space. The other type of the New Town redevelopment with residential and commercial uses shows the greater net increase, $35.0 \%$, in housing within the same contour. The same calculation results for NT_OpenSpace2 and NT_Com2 are 1.7\% and 14.5\%, respectively. The net effects for NT_OpenSpace3 and NT_Com3 are $0.2 \%$ and $-0.05 \%$, respectively. This indicates that the net impacts on housing prices of redevelopment plan announcements fall with distance from each type of the New Town project site.

Finally, and perhaps most important, the results show that the net effects of revitalization neighborhood are different between two redevelopments with different mixed land uses. Within all three contours, the net effects of redevelopment with commercial uses are a lot greater than those of redevelopment with parks. Furthermore, the sign of NT_Com 2 changes from negative in 2002 to positive in 2005 even though it is not significant in both years. This implies that households are willing to pay more for neighborhood with commercial stores rather than that with parks by controlling other variables. In addition, the accessibility variables for commercial store (A_Com) and park (A_Park) show the similar results. While the coefficient of A_Com is significantly negative in both 2002 and 2005 and the coefficient of A_Park is never significant, the

${ }^{14} 0.182=\left(e^{0.167}-1\right)$, where $0.167=(-0.048-(-0.216))$. 
coefficient of A_Com is a lot bigger than one of A_Park in terms of the absolute value. This indicates that households prefer houses closer to neighborhood store while they are not willing to pay more for house close to park. It is important to note that neighborhood spillovers of redevelopment on surrounding housing prices depend on the distance as well as the type of mixed land uses.

\subsection{Conclusion}

Strategy of mixed land uses has been accepted by policymakers to revitalize inner-city neighborhoods in Seoul. This study analyzed the impacts of the New Town redevelopment on housing prices in Seoul. These impacts were found using a pre-post approach that involves the estimation of the spatial hedonic functions for the before and after periods. The regression analysis for spatial dependence showed that the spatial model is valid for the housing market in Seoul. The empirical results provide evidence that the effects of neighborhood revitalization have occurred before the project is completed.

This paper shows that revitalization neighborhood spillovers depend on not only the distance from the New Town redevelopment areas but also the type of mixed land uses. Housing prices within one kilometer of residential redevelopment mixed with open space were $18.2 \%$ higher than elsewhere. If the residential redevelopment is mixed mainly with commercial uses, houses that are within one kilometer of redevelopment have a significantly higher value of $35 \%$ compared to those farther away. Neighborhood spillovers of redevelopment dramatically fall with the distance from the redevelopment

areas. Furthermore, this result shows that the net effects of revitalization neighborhood 
are greater in the case of residential redevelopment with commercial uses than that dominated with public parks.

The results for accessibility to commercial stores and public parks also provide consistent evidence that households are willing to pay for the premium associated with accessibility to neighborhood commercial malls while the premium associated with public parks is not significant. Finally, the research revealed that households prefer to live in denser residential areas. This finding is consistent to new urbanist design principle. Overall, the findings suggest that residents prefer living in neighborhood with mixed land uses. However, more important is the finding that the neighborhood spillover effects depend on the type of mixed land uses. The results in this paper confirm that both the mix of land use and type of mixed land uses matter.

The empirical results for structural characteristics and accessibility characteristics are consistent with the findings from the previous literature. The common perception that education matters in Seoul is confirmed by the findings that households with high-school children are willing to pay premium for a good school district and housing prices fall with distance from a school. 


\section{Appendix 4.A The Results for 2001 and 2004}

Table 4.A1 and 4.A2 show the results of regression for 2001 and 2004, respectively. The results for 2001 are very similar to the results for 2002. The overall results for 2004 are also similar to those for 2005, except the significance and magnitude of the coefficients for the contour dummy variables. NT_OpenSpace1 and NT_Com1 have the significant and negative signs. This implies that negative externalities of distressed neighborhood exist in the proximity to the New Town redevelopment areas. The net effects of the announcement of the New Town redevelopment are $2.1 \%$ and 20.1\% between 2002 and 2004 for NT_OpenSpace1 and NT_Com1, respectively. 
Table 4.A1 Estimation Results for 2001

\begin{tabular}{|c|c|c|c|c|}
\hline Variable & OLS & SAR & SEM & GSAR \\
\hline$\rho$ & & $\begin{array}{l}0.058 \\
(2.32)\end{array}$ & & $\begin{array}{l}0.036^{* * * *} \\
(2.63)\end{array}$ \\
\hline$\lambda$ & & & $\begin{array}{l}0.531 * * * \\
(5.73)\end{array}$ & $\begin{array}{l}0.542 * * * \\
(12.29)\end{array}$ \\
\hline constant & $\begin{array}{l}-1.3186^{* * *} \\
(-18.22)\end{array}$ & $\begin{array}{l}-1.309^{* * *} \\
(-21.80)\end{array}$ & $\begin{array}{l}-1.273^{* * *} \\
(-22.44)\end{array}$ & $\begin{array}{l}-1.271^{* * *} \\
(-21.39)\end{array}$ \\
\hline Age & $\begin{array}{l}-0.1397 * * * \\
(-10.46)\end{array}$ & $\begin{array}{l}-0.141^{* * *} \\
(-27.71)\end{array}$ & $\begin{array}{l}-0.140 * * * \\
(-28.77)\end{array}$ & $\begin{array}{l}-0.141^{* * *} \\
(-28.50)\end{array}$ \\
\hline Age_Square & $\begin{array}{l}0.0105^{* * *} \\
(10.33)\end{array}$ & $\begin{array}{l}0.011^{* * *} \\
(58.42)\end{array}$ & $\begin{array}{l}0.010^{* * *} \\
(58.74)\end{array}$ & $\begin{array}{l}0.010^{* * *} \\
(58.48)\end{array}$ \\
\hline Age_Cubed & $\begin{array}{l}-0.0002 * * * \\
(10.27)\end{array}$ & $\begin{array}{l}-0.0002 * * * \\
(-532.40)\end{array}$ & $\begin{array}{l}-0.0002^{* * *} \\
(-444.11)\end{array}$ & $\begin{array}{l}-0.0002^{* * *} \\
(-465.16)\end{array}$ \\
\hline Floor_Space & $\begin{array}{l}0.0623^{* * *} \\
(32.03)\end{array}$ & $\begin{array}{l}0.070^{* * *} \\
(32.20)\end{array}$ & $\begin{array}{l}0.063^{* * *} \\
(34.39)\end{array}$ & $\begin{array}{l}0.063^{* * *} \\
(33.24)\end{array}$ \\
\hline N_Bedroom & $\begin{array}{l}0.1475^{* * *} \\
(6.79)\end{array}$ & $\begin{array}{l}0.145^{* * *} \\
(6.73)\end{array}$ & $\begin{array}{l}0.147 * * * \\
(7.24)\end{array}$ & $\begin{array}{l}0.146^{* * *} \\
(6.96)\end{array}$ \\
\hline PopDensity & $\begin{array}{l}0.0497 * * * \\
(4.76)\end{array}$ & $\begin{array}{l}0.051 * * * \\
(4.92)\end{array}$ & $\begin{array}{l}0.063 * * * \\
(5.87)\end{array}$ & $\begin{array}{l}0.063 * * * \\
(5.84)\end{array}$ \\
\hline School_District & $\begin{array}{l}0.475 * * * \\
(17.13)\end{array}$ & $\begin{array}{l}0.468^{* * * *} \\
(17.69)\end{array}$ & $\begin{array}{l}0.494 * * * \\
(17.53)\end{array}$ & $\begin{array}{l}0.493 * * * \\
(17.45)\end{array}$ \\
\hline D_School & $\begin{array}{l}-0.016^{* * *} \\
(-4.10)\end{array}$ & $\begin{array}{l}-0.016^{* * *} \\
(-4.06)\end{array}$ & $\begin{array}{l}-0.015 * * * \\
(-3.89)\end{array}$ & $\begin{array}{l}0.014^{* * * *} \\
(-3.85)\end{array}$ \\
\hline A_CBD & $\begin{array}{l}-0.019 * * * \\
(-20.70)\end{array}$ & $\begin{array}{l}-0.019 * * * \\
(-20.77)\end{array}$ & $\begin{array}{l}-0.020 * * * \\
(-20.66)\end{array}$ & $\begin{array}{l}-0.020 * * * \\
(-20.48)\end{array}$ \\
\hline A_Subway & $\begin{array}{l}-0.015^{* * *} \\
(-5.89)\end{array}$ & $\begin{array}{l}-0.015^{* * *} \\
(-5.82)\end{array}$ & $\begin{array}{l}-0.014 * * * \\
(-5.74)\end{array}$ & $\begin{array}{l}-0.014 * * * \\
(-5.73)\end{array}$ \\
\hline A_Commercial & $\begin{array}{l}-0.024 * * * \\
(-5.00)\end{array}$ & $\begin{array}{l}-0.024 * * * \\
(-5.08)\end{array}$ & $\begin{array}{l}-0.020^{* * *} \\
(-4.38)\end{array}$ & $\begin{array}{l}0.020^{* * * *} \\
(-4.30)\end{array}$ \\
\hline A_Park & $\begin{array}{l}-0.005 \\
(-0.40)\end{array}$ & $\begin{array}{l}-0.005 \\
(-0.42)\end{array}$ & $\begin{array}{l}-0.006 \\
(-0.53)\end{array}$ & $\begin{array}{l}0.006 \\
(-0.51)\end{array}$ \\
\hline NT_OpenSpace1 & $\begin{array}{l}-0.145^{* * *} \\
(-4.73)\end{array}$ & $\begin{array}{l}-0.145 * * * \\
(-4.80)\end{array}$ & $\begin{array}{l}-0.150 * * * \\
(-4.77)\end{array}$ & $\begin{array}{l}-0.150 * * * \\
(-4.78)\end{array}$ \\
\hline NT_OpenSpace2 & $\begin{array}{l}0.018 \\
(0.61)\end{array}$ & $\begin{array}{l}0.019 \\
(0.64)\end{array}$ & $\begin{array}{l}0.024 \\
(0.79)\end{array}$ & $\begin{array}{l}0.024 \\
(0.80)\end{array}$ \\
\hline NT_OpenSpace3 & $\begin{array}{l}0.001 \\
(0.05)\end{array}$ & $\begin{array}{l}0.001 \\
(0.05)\end{array}$ & $\begin{array}{l}-0.030 \\
(-1.13)\end{array}$ & $\begin{array}{l}-0.031 \\
(-1.13)\end{array}$ \\
\hline NT_Com1 & $\begin{array}{l}-0.390^{* * *} \\
(-3.86)\end{array}$ & $\begin{array}{l}-0.386^{* * *} \\
(-3.87)\end{array}$ & $\begin{array}{l}-0.370 * * * \\
(-3.78)\end{array}$ & $\begin{array}{l}-0.367 * * * \\
(-3.78)\end{array}$ \\
\hline NT_Com2 & $\begin{array}{l}-0.041 \\
(-0.71)\end{array}$ & $\begin{array}{l}-0.045 \\
(-0.77)\end{array}$ & $\begin{array}{l}-0.014 \\
(-0.23)\end{array}$ & $\begin{array}{l}-0.013 \\
(-0.22)\end{array}$ \\
\hline NT_Com3 & $\begin{array}{l}0.103 \\
(1.39)\end{array}$ & $\begin{array}{l}0.097 \\
(1.32)\end{array}$ & $\begin{array}{l}0.088 \\
(1.20)\end{array}$ & $\begin{array}{l}0.085 \\
(1.17)\end{array}$ \\
\hline $\mathrm{R}^{2}$ & 0.87 & 0.87 & 0.88 & 0.88 \\
\hline LM & $210.5^{* * *}$ & $203.9 * * *$ & & \\
\hline Observations & 1890 & 1890 & 1890 & 1890 \\
\hline
\end{tabular}

Note: The parenthesis is $\mathrm{t}$ value; ${ }^{* *}, \mathrm{p}<0.01$; $^{* *}, \mathrm{p}<0.05$; $^{*}, \mathrm{p}<0.1$. 
Table 4.A2 Estimation Results for 2004

\begin{tabular}{|c|c|c|c|c|}
\hline Variable & OLS & SAR & SEM & GSAR \\
\hline$\rho$ & & $\begin{array}{l}0.126^{* * *} \\
(4.92)\end{array}$ & & $\begin{array}{l}0.052 * * * \\
(2.97)\end{array}$ \\
\hline$\lambda$ & & & $\begin{array}{l}0.594 * * * \\
(15.00)\end{array}$ & $\begin{array}{l}0.590^{* * *} \\
(14.81)\end{array}$ \\
\hline constant & $\begin{array}{l}-1.117^{* * *} \\
(12.62)\end{array}$ & $\begin{array}{l}-1.096^{* * *} \\
(14.97)\end{array}$ & $\begin{array}{l}-1.039^{* * *} \\
(-14.54)\end{array}$ & $\begin{array}{l}-1.039 * * * \\
(-14.54)\end{array}$ \\
\hline Age & $\begin{array}{l}-0.161^{* * * *} \\
(-9.88)\end{array}$ & $\begin{array}{l}-0.162 * * * \\
(-26.15)\end{array}$ & $\begin{array}{l}-0.160^{* * *} \\
(-26.78)\end{array}$ & $\begin{array}{l}-0.160 * * * \\
(-26.78)\end{array}$ \\
\hline Age_Square & $\begin{array}{l}0.014 * * * \\
(11.14)\end{array}$ & $\begin{array}{l}0.014 * * * \\
(62.41)\end{array}$ & $\begin{array}{l}0.013 * * * \\
(62.28)\end{array}$ & $\begin{array}{l}0.013^{* * * *} \\
(62.26)\end{array}$ \\
\hline Age_Cubed & $\begin{array}{l}-0.0003^{* * *} \\
(-10.97)\end{array}$ & $\begin{array}{l}-0.0003 * * * \\
(-436.13)\end{array}$ & $\begin{array}{l}-0.0003 * * * \\
(-384.98)\end{array}$ & $\begin{array}{l}-0.0003^{* * *} \\
(-385.38)\end{array}$ \\
\hline Floor_Space & $\begin{array}{l}0.050^{* * *} \\
(21.07)\end{array}$ & $\begin{array}{l}0.050 * * * \\
(20.96)\end{array}$ & $\begin{array}{l}0.050^{* * *} \\
(22.28)\end{array}$ & $\begin{array}{l}0.050 * * * \\
(22.28)\end{array}$ \\
\hline N_Bedroom & $\begin{array}{l}0.093^{* * *} \\
(3.50)\end{array}$ & $\begin{array}{l}0.089 * * * \\
(3.39)\end{array}$ & $\begin{array}{l}0.090^{* * *} \\
(3.58)\end{array}$ & $\begin{array}{l}0.089 * * * \\
(3.56)\end{array}$ \\
\hline PopDensity & $\begin{array}{l}0.129 * * * \\
(10.07)\end{array}$ & $\begin{array}{l}0.129 * * * \\
(10.30)\end{array}$ & $\begin{array}{l}0.151^{* * *} \\
(11.50)\end{array}$ & $\begin{array}{l}0.151^{* * *} \\
(11.50)\end{array}$ \\
\hline School_District & $\begin{array}{l}0.766^{* * * *} \\
(22.59)\end{array}$ & $\begin{array}{l}0.739 * * * \\
(22.49)\end{array}$ & $\begin{array}{l}0.792^{* * * *} \\
(23.15)\end{array}$ & $\begin{array}{l}0.790^{* * * *} \\
(23.10)\end{array}$ \\
\hline D_School & $\begin{array}{l}-0.017 * * * \\
(-3.58)\end{array}$ & $\begin{array}{l}-0.016^{* * *} \\
(-3.48)\end{array}$ & $\begin{array}{l}-0.015^{* * *} \\
(-3.29)\end{array}$ & $\begin{array}{l}-0.015^{* * *} \\
(-3.28)\end{array}$ \\
\hline A_CBD & $\begin{array}{l}-0.020^{* * *} \\
(-17.81)\end{array}$ & $\begin{array}{l}-0.020^{* * *} \\
(-17.41)\end{array}$ & $\begin{array}{l}-0.022^{* * *} \\
(-18.53)\end{array}$ & $\begin{array}{l}-0.022^{* * *} \\
(-18.50)\end{array}$ \\
\hline A_Subway & $\begin{array}{l}-0.013 * * * \\
(-4.18)\end{array}$ & $\begin{array}{l}-0.012 * * * \\
(-4.02)\end{array}$ & $\begin{array}{l}-0.013 * * * \\
(-4.22)\end{array}$ & $\begin{array}{l}-0.013 * * * \\
(-4.20)\end{array}$ \\
\hline A_Commercial & $\begin{array}{l}-0.043^{* * *} \\
(-7.38)\end{array}$ & $\begin{array}{l}-0.043^{* * *} \\
(-7.43)\end{array}$ & $\begin{array}{l}-0.037 * * * \\
(-6.62)\end{array}$ & $\begin{array}{l}-0.037 * * * \\
(-6.64)\end{array}$ \\
\hline A_Park & $\begin{array}{l}-0.002 \\
(-0.11)\end{array}$ & $\begin{array}{l}-0.003 \\
(-0.17)\end{array}$ & $\begin{array}{l}-0.004 \\
(-0.30)\end{array}$ & $\begin{array}{l}-0.004 \\
(-0.29) \\
\end{array}$ \\
\hline NT_OpenSpace1 & $\begin{array}{l}-0.184 * * * \\
(-4.91)\end{array}$ & $\begin{array}{l}-0.183^{* * *} \\
(-4.97)\end{array}$ & $\begin{array}{l}-0.194 * * * \\
(-5.12)\end{array}$ & $\begin{array}{l}-0.195^{* * *} \\
(-5.14)\end{array}$ \\
\hline NT_OpenSpace2 & $\begin{array}{l}0.038 \\
(1.02)\end{array}$ & $\begin{array}{l}0.041 \\
(1.12)\end{array}$ & $\begin{array}{l}0.044 \\
(1.21)\end{array}$ & $\begin{array}{l}0.045 \\
(1.22) \\
\end{array}$ \\
\hline NT_OpenSpace3 & $\begin{array}{l}0.027 \\
(0.82) \\
\end{array}$ & $\begin{array}{l}0.026 \\
(0.79)\end{array}$ & $\begin{array}{l}-0.009 \\
(-0.28) \\
\end{array}$ & $\begin{array}{l}-0.010 \\
(-0.30) \\
\end{array}$ \\
\hline NT_Com1 & $\begin{array}{l}-0.285^{* *} \\
(-2.32)\end{array}$ & $\begin{array}{l}-0.280 * * \\
(-2.31)\end{array}$ & $\begin{array}{l}-0.269^{* *} \\
(-2.30)\end{array}$ & $\begin{array}{l}-0.272 * * \\
(-2.32)\end{array}$ \\
\hline NT_Com2 & $\begin{array}{l}-0.023 \\
(-0.32) \\
\end{array}$ & $\begin{array}{l}-0.027 \\
(-0.39)\end{array}$ & $\begin{array}{l}0.006 \\
(0.08) \\
\end{array}$ & $\begin{array}{l}0.007 \\
(0.09) \\
\end{array}$ \\
\hline NT_Com3 & $\begin{array}{l}0.069 \\
(0.76) \\
\end{array}$ & $\begin{array}{l}0.057 \\
(0.63)\end{array}$ & $\begin{array}{l}0.046 \\
(0.52) \\
\end{array}$ & $\begin{array}{l}0.045 \\
(0.51) \\
\end{array}$ \\
\hline $\mathrm{R}^{2}$ & 0.80 & 0.81 & 0.82 & 0.82 \\
\hline LM & $332.8 * * *$ & $291.5 * * *$ & & \\
\hline Observations & 1890 & 1890 & 1890 & 1890 \\
\hline
\end{tabular}

Note: The parenthesis is $\mathrm{t}$ value; ${ }^{* *}, \mathrm{p}<0.01 ;{ }^{* *}, \mathrm{p}<0.05$; $^{*}, \mathrm{p}<0.1$. 


\section{Chapter 5}

\section{Summary and Conclusion}

The Korean government has exercised control over land development for residential use. Although the purposes of land-use regulations are to suppress speculation in real estate and to stabilize housing prices, it is alleged that government has failed in achieving those goals. This dissertation tries to address why the purposes of a government has not been met by examining the impacts of government intervention into the housing market on housing prices by considering the macro and micro forces and employing public choice theory.

Chapter 2 provides a theoretical background of a macro approach. To analyze the impacts of macroeconomic variables on housing prices over time, the housing markets are divided into two different but related markets: the market for housing services and the housing capital market. Although the rent is determined in the market for housing services and the function of the market for housing capital is to determine housing price, the stock-flow model can be used to link these two markets and to investigate the effect of each variable on housing prices and rent. Therefore, the stock-flow model is used to analyze aggregate models of the housing market. Following an extensive review of studies, Chapter 2 also develops the theoretical stock-flow model for the Korean housing market by taking account of borrowing constraints.

Chapter 3 examines the impacts of land-use regulations on housing prices with time-series analysis. Even though many articles have claimed that the Korean housing market has been land restrictive, there is no empirical paper that has analyzed how landuse regulations affect the Korean housing market. This essay performs the empirical 
analysis of the effects of land-use regulations on the Korean housing market using a timeseries econometric approach. The empirical results suggest that land-use regulations not only have constrained housing but also have affected the expectation about the future appreciation of housing prices. This expectation affects the current demand for housing which in turn changes housing prices. Therefore, land-use regulations result in higher housing prices by causing the shortage of housing production as well as by stimulating demand for housing.

In addition, the empirical results of Chapter 3 confirm that the existence of borrowing constraints is evident in the Korean housing financial market. Furthermore, it is suggested that housing prices play a greater role in determining homeownership demand than user cost and Chonsei rent. With respect to housing supply, Muth's stock adjustment model is used for housing construction in the Korean housing market. Government intervention into housing construction is found to escalate the speed at which the stock adjusts toward equilibrium through new construction. This result implies that the government recently has responded to housing markets by developing land supply and involving in housing construction.

Chapter 4 exploits a micro approach to analyze the impacts of the New Town redevelopment on neighboring housing prices in Seoul. These impacts are investigated with a pre-post approach that involves the estimation of the spatial hedonic functions for the before and after time periods. Since redevelopment consists of two different types, this model estimates the neighborhood spillovers of different type of redevelopment on surrounding housing prices. 
The regression analysis shows that spatial dependence is evident in the Seoul housing market. The result of a pre-post model suggests that housing markets anticipate the future effects of the completed project. The basic findings imply that the neighborhood spillover effects of redevelopment depend on the type of mixed land uses and the distance from redevelopment area. The results in this paper confirm that both the mix of land use and type of mixed land uses matter. Furthermore, the result for population density presents evidence that households prefer denser and more compact residential areas which is advocated by new urbanism.

Since it seems likely that the Korean government has not met its two purposes of suppressing speculation in real estate and stabilizing housing prices, it is important to analyze how land-use regulations influence the housing market. The basic finding of this dissertation is that a government policy affects the people's expectation. Therefore, the expectation of people about a government policy should be taken into account when a government performs a policy. In addition, this dissertation finds that spatial dependence exists in the Korean housing market and should be correctly specified in the hedonic housing price model.

Since the people's expectation is affected by future land-use policy as well as current land-use regulation, this dissertation needs to be extended to forecasting housing prices affected by different future land-use policies. Under the scenarios of constant, more restrictive, and less restrictive land supply, policy simulation can be conducted to forecast housing prices and construction. Furthermore, the empirical results of this dissertation suggest that land-use regulation has stimulated housing demand rather than 
stabilized housing prices. Therefore, other alternatives such as tax policies should be considered to meet the purposes of a government.

Finally, more research should be conducted to address the following question: if government regulations are not efficiently stabilizing housing prices, why has the government not deregulated substantially? Since public land developers are governmentsupported, they have incentives of using land-use regulations in order to pursue private goals rather than social welfare. Public choice theory models the activities of government as the result of a political process in which political agents respond to the private incentives they face. Public choice model can be employed to explain why the government has had land-use regulations. Failure of achieving the government's goals provides considerable opportunities for future research in this area. 


\section{References:}

Alberts, William W. (1962). Business cycles, residential construction cycles, and the mortgage market, The Journal of Political Economy, 70(3), 263-281.

Alonso, William. (1964). "Location and Land Use”, Harvard University Press. Cambridge, MA.

Anselin, Luc. (1988). Spatial Econometrics: Methods and Models. Studies in Operational Regional Science Series. Kluwer Academic Publishing, Norwell, MA.

Acharya, Gayatri and Lynne Lewis Bennett. (2001). Valuing Open Space and Land-Use Patterns in Urban Watersheds, Journal of Real Estate Finance and Economics, 22(2/3), 221-237.

Asabere, Paul K. and Forrest E. Huffman. (1996). Negative and positive impacts of golf course proximity on home prices, The Appraisal Journal, 351-355.

Bae, Hang-Hee Christine, Myung-Jin Jun, and Hyeon Park. (2003). The impact of Seoul's subway Line 5 on residential property values. Transport Policy, 10, 8594.

Benson, Earl. D., Julia L. Hansen, Arthur L. Schwartz, and Greg T. Smersh. (1998). Pricing residential amenities: the value of a view, Journal of Real Estate Finance and Economics 16(1), 55-73.

Bohl, Charles C. (2000). New Urbanism and the City: Potential Applications and Implications for Distressed Inner-City Neighborhoods. Housing Policy Debate 11, 761-801.

Boyes, William J., William Stewart Mounts, and Clifford Sowell. (1988) The Federal Reserve as an Bureaucracy: An Examination of Expense-Preference Behavior. Journal of Money, Credit, and Banking 20, No.2(May).

Brady, Eugene A. (1967). A sectoral econometric study of the postwar residentialhousing market, Journal of Political Economy, 75(2), 147-158.

Braid, R. M. (1988). Uniform spatial growth with perfect foresight and durable housing, Journal of Urban Economics, 23(1), 41-59.

Buchanan, James M. (1990). The Domain of Constitutional Economics. Constitutional Political Economy 1, No. 1(Winter).

Cao, Than Van and Dennis C. Cory. (1981). Mixed land uses, land-use externalities, and residential property values: a reevaluation. Annals of Regional Science 16, 1-24. 
Capozza, Dennis and Paul J. Seguin. (1996). Expectations, Efficiency, and Euphoria in the Housing Market, Regional Science and Urban Economics, 26(3-4), 369-386.

Case, Karl E, and Robert J. Shiller. (1989). The Efficiency of the Market for Single Family Homes, American Economic Review, 79(1):125-137.

Choi, Eun Young. (2004). The increasing of residential segregation and the differentiation of educational environment in Seoul. Ph.D. dissertation. Seoul National University, Korea. (in Korean)

Clark, Todd E. (1995). Rents and Prices of Housing across Areas of the United States: A Cross-Section Examination of the Present Value Model, Regional Science and Urban Economics, 25(2), 237-47.

Clayton, Jim. (1997). Are Housing Price Cycles Driven by Irrational Expectations?, Journal of Real Estate Finance and Economics, 14(3), 341-363.

Dipasquale, Denise. (1999). Why Don't We Know More About Housing Supply?, Journal of Real Estate Finance and Economics, 18(1):9-23.

DiPasquale, Denise and Edward L. Glaeser. (1999). Incentives and Social Capital: Are Homeowners Better Citizens?, Journal of Urban Economics 45, 354]384

Dipasquale, Denise, and William C. Wheaton. (1996). "Urban Economics and Real Estate Markets", Prentice Hall, Englewood Cliffs, NJ.

Dipasquale, Denise, and William C. Wheaton. (1994). Housing Market Dynamics and the Future of Housing Prices, Journal of Urban Economics, 35(1):1-27.

Dipasquale, Denise, and William C. Wheaton. (1992). The cost of capital, tax reform, and the future of the rental housing market, Journal of Urban Economics, 31(3):337359.

Dougherty, Ann and Van Order Robert. (1982). Inflation, housing costs and the consumer price index, American Economic Review, 72(1), 154-164.

Follain, James R. (1982). Does Inflation Affect Real Behavior: The Case of Housing, Southern Economic Journal 48(3), 570-82.

Follain, James R. and David C. Ling. (1991). The Federal Tax Subsidy to Housing and the Reduced Value of the Mortgage Interest Deduction, National Tax Journal 44(2), 147-68

Garrett, Thomas A. and Russell Sobel. (2003). The Political Economy of FEMA Disaster Payments. Economic Inquiry, 41(3). 
Geoghegan, Jacqueline, Lisa A. Wainger, and Nancy E. Bockstael. (1997). Spatial landscape indices in a hedonic framework: an ecological economics analysis using GIS. Ecological Economics 23, 251- 264.

Green, Richard K. and Kerry D. Vandell. (1999). Giving Households Credit: How Changes in the U.S. Tax Code Could Promote Homeownership, Regional Science and Urban Economics, 29(4), 419-444.

Grier, Kevin Blaine. (1987). Presidential Elections and Federal Reserve Policy: An Empirical Test, Southern Economic Journal, 54(2)

Grudnitski, Gary and Quang Do (1997). Adjusting the value of houses located on a golf course, The Appraisal Journal, 261-266.

Guttentag, Jack M. (1961). The Short Cycle in Residential Construction, American Economic Review, 51(3).

Hannah, Lawrence, Kyung-Hwan Kim, and Edwin S. Mills. (1993). Land Use Controls and Housing Prices in Korea, Urban Studies, 30(1):147-156.

Henneberry, John. (1998). Transport Investment and house prices. Journal of Property Valuation and Investment, 16 (2), 144-158.

Housing and Commercial Bank. (1996). Housing Economic Statistical Yearbook, Seoul: Housing and Commercial Bank.

Irwin, Elena G. (2002). The effects of open space on residential property values. Land Economics 78 (4), 465- 480.

Irwin, Elena G. and Nancy E. Bockstael. (2001). The problem of identifying land use spillovers: measuring the effects of open space on residential property values. American Journal of Agricultural Economics 83 (3), 698- 704.

Kearl, J. R. (1979). Inflation, mortgages and housing, The Journal of Political Economy, 87(5), 1115-1138.

Kim, Chong Won, Time T. Phipps, and Luc Anselin. (2003). Measuring the benefits of air quality improvement: a spatial hedonic approach. Journal of Enviromental Economics and Management 45, 24-39.

Kim, Chung-Ho, and Kyung-Hwan Kim. (2000). The Political Economy of Korean Government Policies on Real Estate, Urban Studies, 37(7):1157-1169.

Kim, Kyung-Hwan. (1993). Housing Prices, Affordability, and Government Policy in Korea, Journal of Real Estate Finance and Economics, 6(1):55-71. 
Kim, Shil-Young. (1997). A Study on the Housing Investment Cycle: the Case of Korea, Housing Studies, 6(1). (in Korean)

Knaap, Gerrit J., Chengri Ding, and Lewis D. Hopkins. (2001). Do plans matter? The effects of light rail plans on land values in station areas. Journal of Planning Education and Research 21 (1), 32-39.

Korea National Housing Corporation. (2003). Yearbook of Housing Statistics, Seoul: Korea National Housing Corporation.

Lee, Bun Song, Eui-Chul Chung, and Yong Hyun Kim. (2005). Dwelling Age, Redevelopment, and Housing Prices: The Case of Apartment Complexes in Seoul. Journal of Real Estate Finance and Economics, 30 (1), 55-80.

Lesage, James. (1999). Spatial Econometrics. Available online: http://www.rri.wvu.edu/WebBook/LeSage/spatial/spatial.html

Li, Mingche.M. and H. James Brown. (1980). Micro-neighborhood externalities and hedonic housing prices. Land Economics 56 (2), 125- 141.

Maisel, Sherman J. (1963). A theory of fluctuations in residential construction starts, American Economic Review, 53(3), 359-383.

Mankiw, Gregory N. and David N. Weil. (1989). The Baby Boom, the Baby Bust, and the Housing Market, Regional science and Urban Economics, 19(2), 235-258.

McDonald, John F. and Clifford I. Osuji. (1995). The effect of anticipated transportation improvement on residential land values. Regional science and Urban Economics $25,261-278$.

Mester, Loretta J. (1994). Further Evidence Concerning Expense Preference and the Fed Journal of Money, Credit, and Banking, 26(1)

Muth, Richard F. (1960). The demand for non-farm housing, in "The Demand for Durable Goods,”(Harberger, Ed.), University of Chicago Press, Chicago.

Myers, Dowell and Elizabeth Gearin. (2001). Current preferences and future demand for denser residential environments, Housing Policy Debate 12 (4), 633-659.

Park, Bae-Gyoon, (1988). Where Do Tigers Sleep at Night ? The State's Role in Housing Policy in South Korea and Singapore. Economic Geography, 74(3).

Park, W. A. and K. Y. Kim. (1999). 1999 housing finance demand analysis, Housing Finance, 218, 60-80. (in Korean) 
Peng, Ruijue, and William C. Wheaton. (1994). Effects of Restrictive Land Supply on Housing in Hong Kong:An Econometric Analysis, Journal of Housing Research, 5(2):263-291.

Poterba, James M. (1984). Tax Subsidies to owner-occupied housing: An asset-market approach, The Quarterly Journal of Economics, 99(4), 729-752.

Quigley, John M. (1979). What have we learned about urban housing market ?, in "Current Issues in Urban Economics" (Mieszkowski and Straszheim, Eds.), Johns Hopkins University Press.

Renaud, Bertrand. (1989). Compounding Financial Repressions with Rigid Urban Regulations: Lessons of the Korean Housing Market, Review of Urban and Regional Development Studies, 1:3-22.

Rosen, Sherwin. (1974). Hedonic prices and implicit markets: product differentiation in pure competition, Journal of Political Economy, 34-55.

Schwab, Robert M. (1982). Inflationary expectations and the demand for housings, American Economic Review, 72(1), 143-153.

Shughart, William F. and Robert D. Tollison. (1983). Preliminary Evidence on the Use of Inputs by the Federal Reserve System. American Economic Review 73, No.3(June).

Sheffrin, Steven. (1983). Rational Expectations. New York: Cambridge University Press.

Smart Communities Network. (2002). Available online: http://www.sustainable.doe.gov/.

Son, Jae-Young. (1997). A Review of the Korean Housing Market and Related Policies, Review of Urban and Regional Development Studies, 9:81-99.

Son, Jae-Young. (1994). A Brave Experiment: Korea's Recent Land Policy Reform and the Role of the Land Holding Tax, Review of Urban and Regional Development Studies, 6:115-134.

Son, Jae-Young, Yun-Hi Won, and Choon-Geol Moon. (2003). Changing Conditions and Quality of Housing, Social Indicators Research, 62, 63:211-237.

Son, Jae-Young, and Kyung-Hwan Kim. (1998). Analysis of urban land shortages: the case of Korean cities, Journal of Urban Economics, 43:362-384.

Song, Yan and Gerrit-Jan Knaap.( 2003). New urbanism and housing values: a disaggregate assessment. Journal of Urban Economics 54, 218- 238.

Song, Yan and Gerrit-Jan Knaap. (2004) Measuring the effects of mixed land uses on housing values, Regional Science and Urban Economics 34, 663-680 
Toma, Mark. (1982). Inflationary Bias of the Federal Reserve System: A Bureaucratic Perspective, Journal of Monetary Economics, 10(2).

$\mathrm{Tu}$, Charles and Mark J. Eppli. (1999). Valuing new urbanism: the case of Kentlands, Real Estate Economics 27 (3), 453-473.

Weaton, William C. (1985). Life-Cycle Theory, Inflation, and the Demand for Housing , Journal of Urban Economics, 18(2), 161-179.

Weaton, William C. (1982). Urban spatial development with durable but replaceable capital, Journal of Urban Economics, 12(1), 53-67.

Yoon, H.I. (1995).Housing finance in Korea: Current state and future challenges, Seoul Korea Housing Bank. (In Korean)

Young, Marily, Michael Reksulak, and William F. Shughart. (2001). The Political Economy of the IRS, Economics and Politics 13(2) 